\title{
Resveratrol in Cancer Patients: From Bench to Bedside
}

\author{
Massimiliano Berretta ${ }^{1, *,+}$, Alessia Bignucolo ${ }^{2,+}{ }^{(\mathbb{C}}$, Raffaele Di Francia ${ }^{3}$, Francesco Comello ${ }^{2}$, \\ Gaetano Facchini ${ }^{4}$ (D), Manuela Ceccarelli ${ }^{5}$ D , Rosario Vincenzo Iaffaioli ${ }^{6}$, \\ Vincenzo Quagliariello ${ }^{7, \ddagger(D)}$ and Nicola Maurea ${ }^{7, \ddagger}$ \\ 1 Department of Medical Oncology-Centro di Riferimento Oncologico di Aviano (CRO), IRCCS, \\ 33081 Aviano, Italy \\ 2 Experimental and Clinical Pharmacology-Centro di Riferimento Oncologico di Aviano (CRO), IRCCS, \\ 33081 Aviano, Italy; alessia.bignucolo@cro.it (A.B.); francesco.comello@cro.it (F.C.) \\ 3 Gruppo Oncologico Ricercatori Italiani, GORI-ONLUS, 33170 Pordenone (PN), Italy; \\ rdifrancia@iapharmagen.com \\ 4 UOC Oncologia, ASL Napoli 2 Nord, P.O. “S.M. delle Grazie”, Pozzuoli-Ischia, 80078 Napoli, Italy; \\ gafacchi@libero.it \\ 5 Department of Clinical and Experimental Medicine, Unit of Infectious Diseases, University of Catania, \\ 95122 Catania, Italy; manuela.ceccarelli86@gmail.com \\ 6 Association for Multidisciplinary Studies in Oncology and Mediterranean Diet, Piazza Nicola Amore, \\ 80138 Naples, Italy; eiaffaioli@libero.it \\ 7 Division of Cardiology, Istituto Nazionale Tumori- IRCCS- Fondazione G. Pascale, 80131 Napoli, Italy; \\ quagliariello.enzo@gmail.com (V.Q.); n.maurea@istitutotumori.na.it (N.M.) \\ * Correspondence: mberretta@cro.it \\ + These authors contributed equally to this work. \\ $\ddagger$ Both co-last author.
}

Received: 14 March 2020; Accepted: 20 April 2020; Published: 22 April 2020

\begin{abstract}
Resveratrol (3,5,4'-trihydroxystilbene) is a natural phytoalexin that accumulates in several vegetables and fruits like nuts, grapes, apples, red fruits, black olives, capers, red rice as well as red wines. Being both an extremely reactive molecule and capable to interact with cytoplasmic and nuclear proteins in human cells, resveratrol has been studied over the years as complementary and alternative medicine (CAM) for the therapy of cancer, metabolic and cardiovascular diseases like myocardial ischemia, myocarditis, cardiac hypertrophy and heart failure. This review will describe the main biological targets, cardiovascular outcomes, physico-chemical and pharmacokinetic properties of resveratrol in preclinical and clinical models implementing its potential use in cancer patients.
\end{abstract}

Keywords: resveratrol; cancer; inflammation; pharmacokinetic; pharmacodynamic; food-drug; personalized medicine; cytochrome P450; complementary medicines

\section{Introduction}

Resveratrol (3,5,4'-trihydroxy-trans-stilbene) is an antimicrobial and antioxidative compound (phytoalexin) with pleiotropic properties, naturally produced by plants and stored in many dietary sources like nuts, grapes, apples, red fruits, black olives, capers, red rice as well as red wines [1,2]. This interesting bioactive compound is well known as an antibacterial, antiviral and anti-inflammatory agent; however, in the last 10 years, researchers worldwide have exponentially increased the study on its biological properties, opening an unprecedented scientific interest in this field $[3,4]$. Notably, resveratrol is one of the most studied polyphenols that naturally accumulates in plant cells, and probably its presence characterizes the antioxidant and anti-inflammatory properties of a specific food [2]. The first studies concerning its chemical-physical structure demonstrated its interaction with the electrons scattered in reactive species of oxygen or other pro-oxidant components [5-7]. The worthwhile 
properties of resveratrol are, however, marked by a pharmacokinetic profile and by an unfavorable oral bioavailability, which requires a thorough analysis. To date, to the best of our knowledge, scientific papers and reviews summarizing multiple characteristics of resveratrol, its pharmacokinetic, pharmacodynamic profiles and potential drug interaction in oncology are lacking in literature. Therefore, this review aimed to describe the potential use of resveratrol in cancer management presenting the main biochemical pathways involved, issues and potential uses in cancer patients. Moreover, the involvement of resveratrol in cardioncology, its potential use for risk reduction of myocardial ischemia, myocarditis, cardiac hypertrophy as well as heart failure are also discussed. To endorse this review, we made a comprehensive search on PubMed, Web of Science and SciFinder. The search terms were "resveratrol" combined with "cardioncology" or "cancer" or "drug-food" or "cardiology" or "pharmacokinetic" or "pharmacodynamic".

\section{Physico-Chemical and Pharmacokinetic Properties of Resveratrol}

Resveratrol is a low molecular weight phyto-polyphenol of 228 Da that appears as an off-white powder with lipophilic properties (octanol/water partition coefficient, $\log \mathrm{Kow}=3.1$ ). Its melting point is between 253 and $255^{\circ} \mathrm{C}$, and its solubility in water is very low $(3 \mathrm{mg} / 100 \mathrm{~mL})$ [8]. The ethylene bridge due to a limited degree of freedom generates two geometric isomers: cis-resveratrol and trans-resveratrol (Figure 1) [5]. These isoforms co-exist in resveratrol extracts even if a greater biological activity and stability are attributed to trans-resveratrol. Comparing to the geometric isomers, the nearly planar structure of trans-resveratrol is less flexible than the non-planar structure of cis-resveratrol, but it possesses a lower repulsive energy that ensures it, albeit small, higher stability. Isomerization of trans-resveratrol to cis-resveratrol occurs via molecule breakdown when trans-resveratrol is exposed to $\mathrm{UV}$ radiation at a wavelength of 254 or $366 \mathrm{~nm}$, to high $\mathrm{pH}$ conditions or in plants during fermentation processes [5,9]. In analyzing some physical-chemical aspects of resveratrol, Zupancic et al. showed how trans-resveratrol is rapidly degradable in high-pH solutions. In particular they demonstrated that trans-resveratrol exponentially decreases its stability and solubility at a $\mathrm{pH}$ ranging from 1.2 to 10 according to first-order kinetics and observing a higher degradation rate at $37^{\circ} \mathrm{C}$ in a $\mathrm{pH} 7.4$ buffer [9]. Since in humans the gastrointestinal tract $\mathrm{pH}$ ranges from 1.5 in the stomach to 8.5 in the intestine, this peculiarity could explain the low bioavailability of orally taken trans-resveratrol.

(a)<smiles>Oc1ccc(/C=C/c2cc(O)cc(O)c2)cc1</smiles>

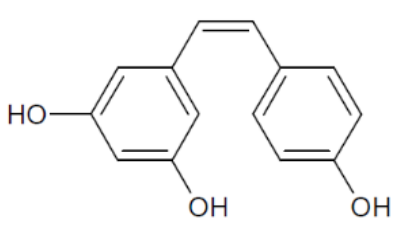

cis-Resveratrol

(b)
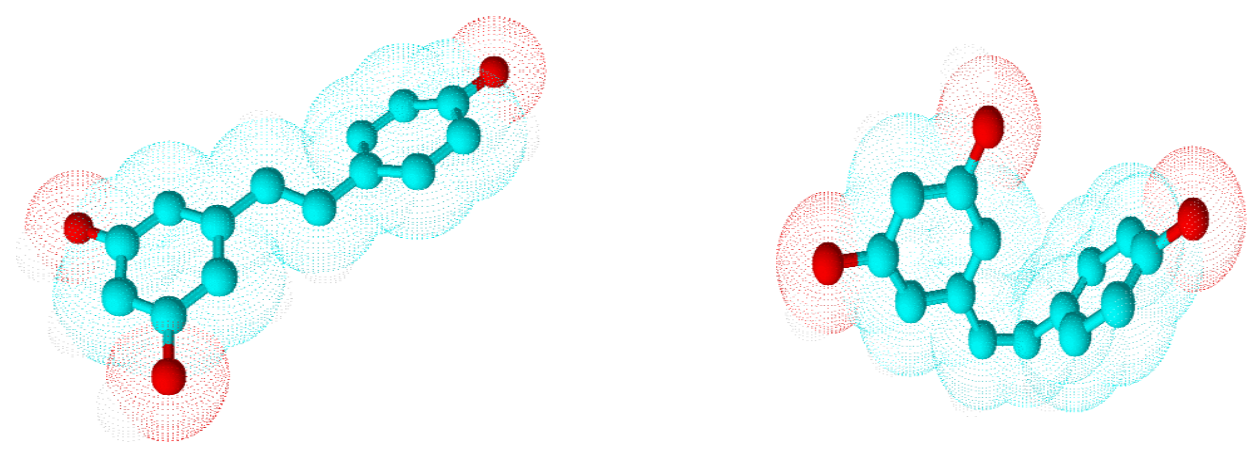

Figure 1. (a) Chemical structures of trans-resveratrol and cis-resveratrol; (b) 3D chemical structures of trans-resveratrol and cis-resveratrol. 
Naturally produced from phenylalanine in response to exogenous stimuli such as fungal infections from Botrytis cinerea, lesions or UV radiation, resveratrol is a phytoalexin present in numerous plants. It was first isolated around the 1940s from Veratrum grandiflorum roots, but the richest source of trans-resveratrol is known to be Polygonum cuspidatum, a plant widely used in traditional Chinese medicine $[10,11]$. Despite the numerous sources and their high variability in content, the use of trans-resveratrol is very limited due to its extensive metabolism (Figure 2) for which in vitro concentration does not reflect the actual concentration when considering administration in humans $[12,13]$. The substantial difference in plasma levels between in vitro and in vivo models partly is due to the rapid degradation and extensive metabolism to which resveratrol is exposed. When orally administered, resveratrol is rapidly absorbed via transepithelial diffusion as demonstrated by Walle et al. using ${ }^{14} \mathrm{C}$-labeled resveratrol. In this investigation, after oral administration of ${ }^{14} \mathrm{C}$ resveratrol in healthy human volunteers, radioactivity was localized in epithelial cells of the gastrointestinal tract, and the absorption rate appeared to exceed $70 \%$ despite the rate of unchanged resveratrol in systemic circulation was extremely low [14]. This result was in line with what was found in other investigations using tritium-labeled resveratrol, in which absorption rates appeared between $70 \%$ and $90 \%[15,16]$. Whilst trans-resveratrol seemed to passively diffuse and permeate the cell membrane, its glycosidic derivative trans-piceid (Figure 3) was seen to accumulate in cells and tissues to a lesser extent, as the absorption across the apical membrane seemed to be governed by the active Sodium-Glucose Transporter 1 (SGLT1) abundant in the small intestine. Only after passing the brush border membrane could trans-piceid then be hydrolyzed by cytosolic- $\beta$-glucosidase or by the membrane-bound lactase phlorizin-hydrolase releasing trans-resveratrol [17-19]. By contrast, trans-piceid, trans-resveratrol and relative conjugates resulted in substrates of the multidrug-related protein 2 (MPR2) and, to a lesser extent, the P-glycoprotein (MDR1), which were responsible for the apical efflux of these stilbenes. The ATP-binding cassette transporter (MRP3), placed in the basolateral membrane, was responsible for the diffusion of resveratrol and derivates into the bloodstream $[17,18]$. The low bioavailability of resveratrol also lies in the extremely organized crystalline structure that establishes its lipophilic nature. Indeed, its volume of distribution $(\mathrm{Vd})$ after intravenous administration resulted about $1.8 \mathrm{~L} / \mathrm{kg}$, suggesting a considerable tissue distribution $[14,16,20]$. Moreover, trans-resveratrol and relative conjugates were found to be distributed mainly in the liver and kidneys, the primary sites of metabolism and excretion, but radioactivity of ${ }^{14} \mathrm{C}$-labeled resveratrol was observed also in the oral cavity, stomach and intestines suggesting a "resveratrol reservoir" of these tissues [14,20]. In accordance with previous investigations, Menet et al. confirmed, in an animal model, that after both single dose and sustained resveratrol intake, the distribution was higher in kidneys and the liver, whereas recently the pharmacokinetic analysis by Su and colleagues demonstrated that the major distribution of resveratrol, derivatives and metabolites occurred in the gastrointestinal tract after oral intake [21,22]. As mentioned above, resveratrol undergoes rapid and extensive metabolism, and several studies were conducted in order to identify resveratrol metabolites. It is alleged that resveratrol is exposed to phase II metabolism in order to reduce it lipophilicity $[14,23]$. The predominant molecular moieties of resveratrol circulating in plasma are its sulfate conjugate and glucuronide conjugate. Sulfation occurs in the liver and intestinal tract where resveratrol is a substrate of sulfotransferase (SULTs) isoforms SULT1A1, SULT1A3 and SULT1E. The major sulfate conjugates seem to be resveratrol-3-O-sulfate, resveratrol-4'-O-sulfate and dihydroresveratrol-sulfate $[12,23,24]$. Likewise, in the liver and intestine resveratrol undergoes glucuronidation carried out by uridine 5'-diphospho-glucuronosyl transferases (UGTs) [24-26]. Aumont and collaborators have proved with in vitro studies involving various UGT isoforms that glucuronic acid conjugation was regio- and stereoselective. Cis-resveratrol glucuronidation occurred 5 to 10 times faster than trans-resveratrol glucuronidation in both 3 and $4^{\prime}$ positions. Moreover, both in trans and cis isoforms conjugation, the 3-position was most promoted. From the analysis carried out with different UGT isoforms, it emerged that UGT1A9 and UGT1A10 exerted their activity toward both cis-resveratrol and trans-resveratrol, whereas UGT1A1 conjugated the 3-O-position of trans-resveratrol in a selective manner. Cis-resveratrol appeared to be selectively glucuronidated 
mainly by UGT1A6 and to a lesser extent by UGT2B7 and UGT2B15 [27]. Conjugation with glucuronid acid and with sulphate represents the rate-limiting step in the bioavailability of resveratrol, and such extensive phase II metabolism is responsible for the very low plasma concentration of free resveratrol. Several pharmacokinetic data in human healthy volunteers corroborated that, after oral administration, a higher concentration (Cmax) of free resveratrol occurred after about $1 \mathrm{~h}$ and was lower than the Cmax of resveratrol conjugates $[14,26,28-30]$. These data were consistent with the evidence, in animal models, that glucuronides and sulphate showed higher plasmatic concentrations than that of trans-resveratrol, confirming the rapid metabolism to which resveratrol undergoes [15,16,31,32]. Newsworthy, in both models a second plasma peak of resveratrol was highlighted, suggesting that resveratrol likely undergoes enteropathic recirculation. It could be assumed that both glucuronic and sulfate moieties undergo deconjugation, carried out by ubiquitous $\beta$-glucuronidases and sulfatases, releasing potentially active resveratrol [14-16,28-31,33,34]. The poor bioavailability of free trans-resveratrol depends not only on the high first-pass metabolism but also on its elevated protein binding. Albumin, indeed, seems to play a key role in establishing resveratrol-albumin complexes, thus concurring to $98.3 \%$ protein binding rate [35-37]. Interestingly the gut microbiota was another active major player in the metabolic pathway of resveratrol (Figure 4). Gut bacteria have proven to be skilled in improving the bioavailability of resveratrol by promoting its synthesis both starting from its precursors, such as piceid, and from its conjugates. In the gut lumen, indeed, all conjugates and metabolites may undergo hydrolysis and thus regenerate resveratrol. Once again, resveratrol may be a substrate of the intestinal bacteria, and it could be metabolized into its reduced form dihydro-resveratrol (DHR), which in turn could be further absorbed, both sulfate and glucuronic conjugated and excreted (Figure 5) [38-40]. Recent data revealed the gut microbiota to be a key player in the recovery of resveratrol. Notably, a study conducted on healthy volunteers revealed that the primary producers of dihydro-resveratrol were both Slackia equolifaciens and Adlercreutzia equolifacens strains. An in vitro testing, conducted with five different probiotic extracts, has also demonstrated that $\beta$-glucosidases, isolated from strains of Lactobacillus acidophilus and Bifidobacteria infantis, were able to catalyze the breakdown of piceid in its aglycone derivate [41]. This evidence, however, shall take into account the wide microbial diversity that may contribute to interindividual differences of resveratrol metabolism, which is the reason why further studies on the role of the gut microbiota with respect to resveratrol biotransformation are needed. Based on pharmacokinetic data collected after the intake of radio-labeled resveratrol in both human and animal models, it could be assumed that the preferential way of excretion of resveratrol and its metabolites is the renal one $[14,16,20]$. Radioactivity indeed was mostly recovered in urine and was very low along the gastrointestinal tract. Consistent with these findings, several other investigations remarked the renal excretion to be the major way of elimination of resveratrol $[22,25,26,28,30,42]$. 


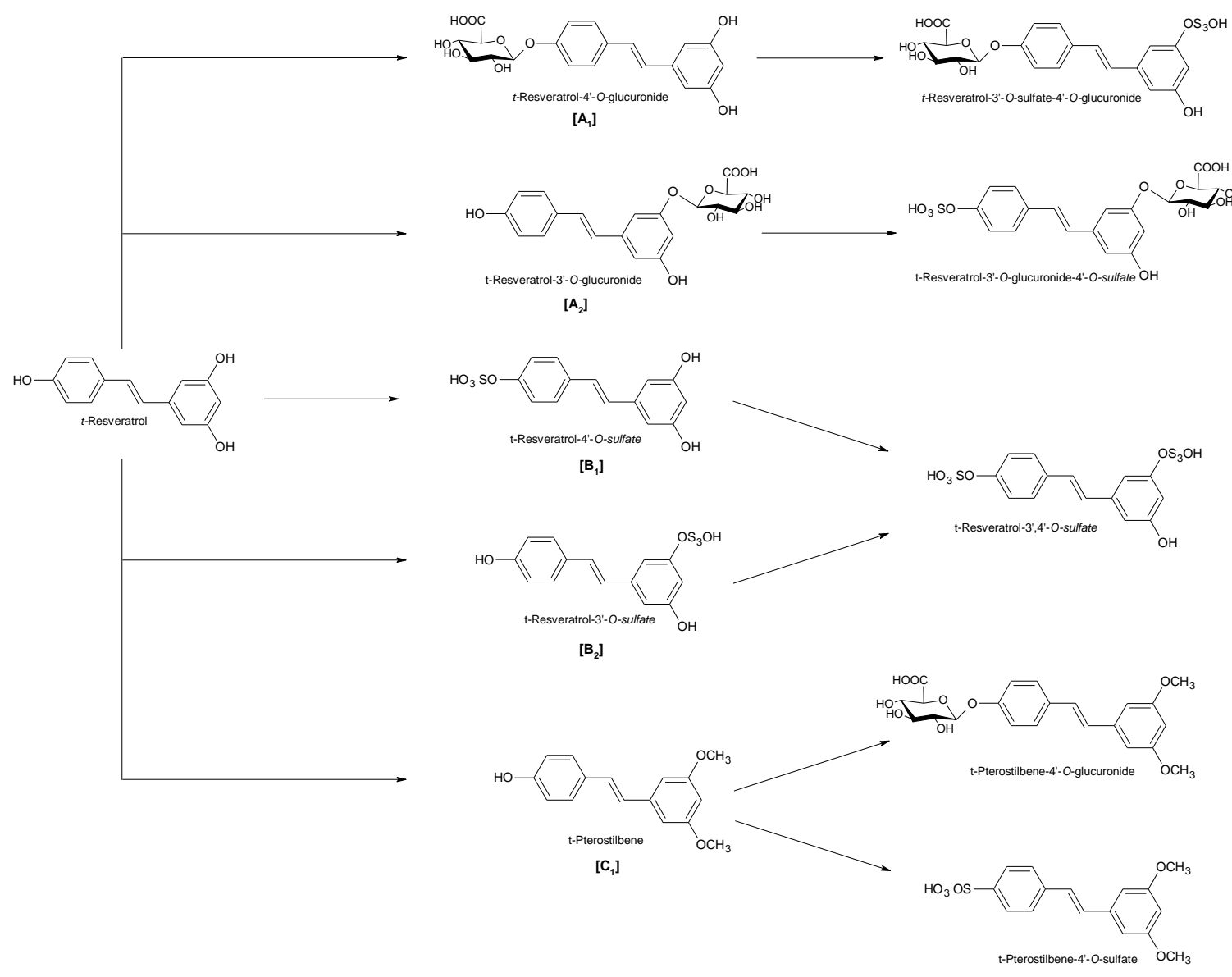

Figure 2. Phase II metabolism of trans-resveratrol. [ $\left.\mathrm{A}_{1}\right]$ : 4'-glucuronic conjugation; $\left[\mathrm{A}_{2}\right]$ : 3-glucuronic conjugation; $\left[\mathrm{B}_{1}\right]$ : $4^{\prime}$-sulfate conjugation; $\left[\mathrm{B}_{2}\right]$ : 3-sulfate conjugation; $\left[\mathrm{C}_{1}\right]$ : 3,5-dimethyl conjugation.

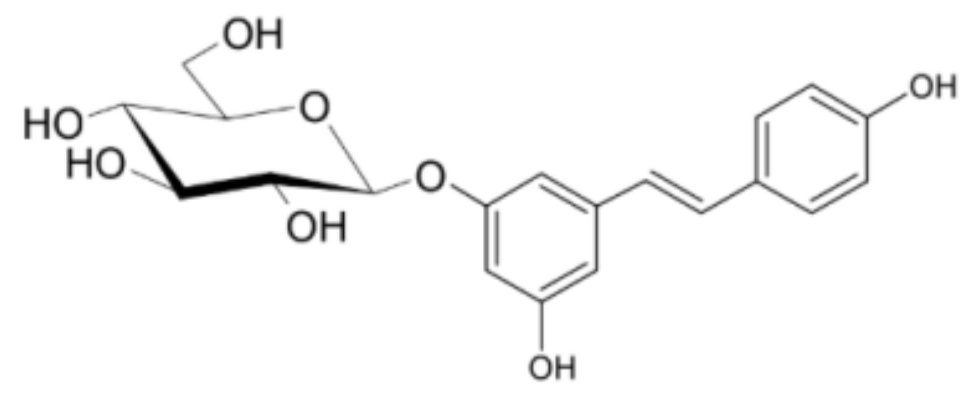

Piceid

Figure 3. Trans-resveratrol-3-O-D-glycoside. 


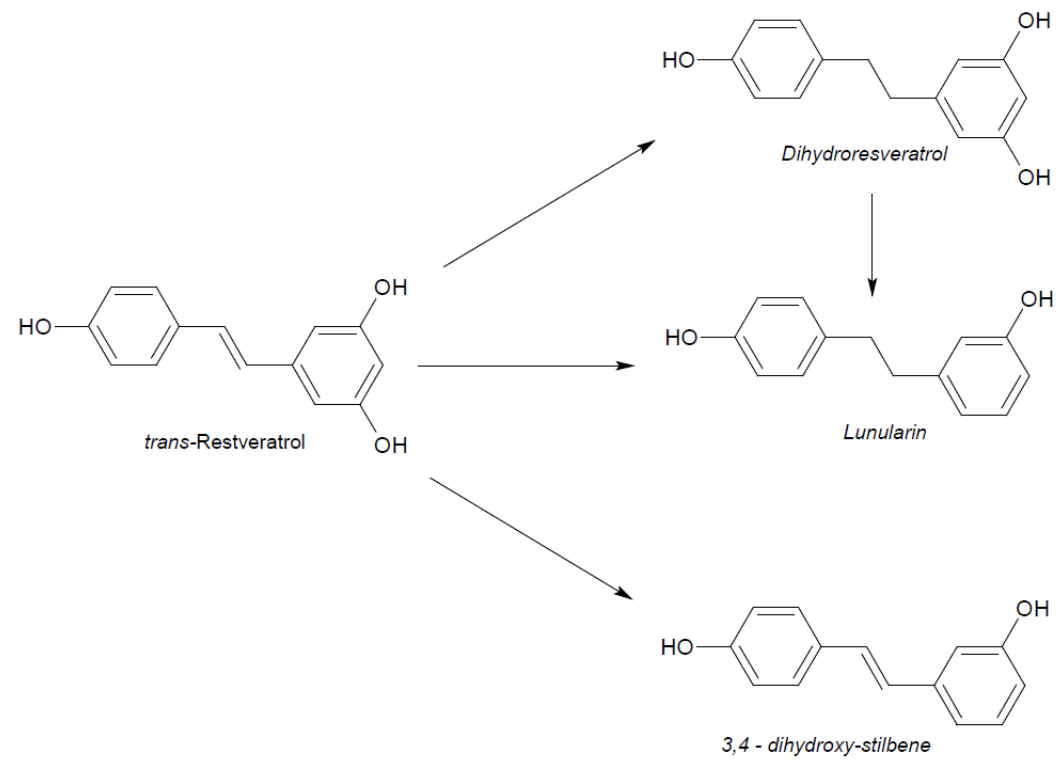

Figure 4. Example of gut microbiota biotransformation of trans-resveratrol.

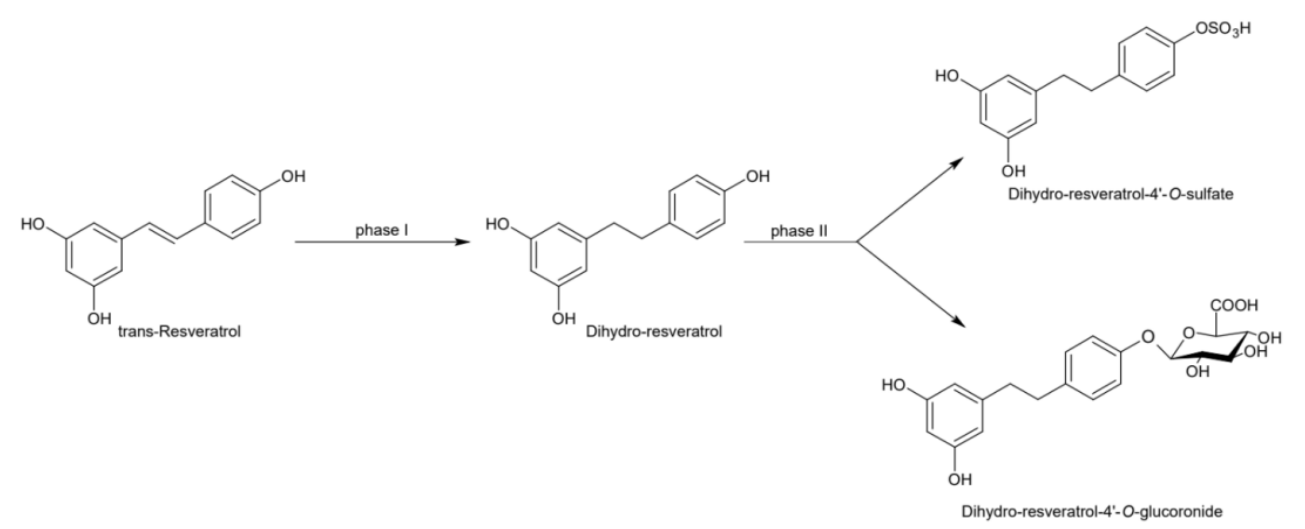

Figure 5. Microbial reduction of trans-resveratrol and conjugation of its main metabolite dihydro-resveratrol.

\section{Pharmacodynamic Properties of Resveratrol}

Resveratrol is a nutraceutical phytoalexin that exerts its activity towards various disorders, despite the fact that its real mechanisms have not been fully understood yet and still remain a major challenge. Resveratrol has a good safety profile and has a wide spectrum of targets despite its employment as an active drug remaining limited due to its low bioavailability [43]. We will briefly describe the main mechanisms of action, so far known, of resveratrol to then deepen its benefits in cancer and cardiovascular diseases (Table 1). Resveratrol has antioxidant properties that ensure it an adjuvant role in all pathologies based on an excess of reactive oxygen species (ROS) production such as tumors, inflammation, cardiovascular disease (CVD), type 2 diabetes mellitus (T2DM) and neurodegenerative diseases. Its capability in contrasting low-density lipoprotein (LDL) oxidation via copper chelation due to its peculiar chemical structure was previously demonstrated [44-46]. Resveratrol was also reported to influence ROS levels both via free-radical scavenging and via upregulation of antioxidant enzymes like superoxide dismutase (SOD), glutathione peroxidase and catalase, which protects the cell from ROS damage, through different mechanisms [47]. Resveratrol, indeed, demonstrated to downregulate Hypoxia-Inducible Factor (HIF-1 $\alpha$ ), a protein widely expressed in cells undergoing hypoxia conditions, thus suppressing glycolytic metabolism [47]. For its structure, this stilbene was able to undergo a redox reaction acting as a quinone reductase and receive electrons from free radicals. A direct inhibition of quinine reductase $2(\mathrm{QR} 2)$ by resveratrol was found to protect cells 
from the oxidative process via induction of antioxidant enzyme activity [48]. Lastly, data highlighted the capability of stilbene to activate p38-mitogen-activated protein kinase (p38-MAPK) signaling and suppress the extracellular signal-regulated kinases (ERK1/2) pathway responsible for increasing ROS levels [49-54]. Two of the main targets of resveratrol are known to be cyclooxygenase isoforms (COX-1 and COX-2), which metabolize arachidonic acid to generate prostaglandins (PG) and thromboxanes (Tx) both implicated in inflammatory response. The interaction of resveratrol with COX-1 and COX-2 leads to pro-inflammatory factors suppression $[55,56]$. Notably the inhibition of COX-1 in the arachidonic acid pathway, via suppression of thromboxanes TxA2, was found to be responsible for the anti-thrombotic activity along with the blockade of the mitogen-activated protein kinase (MAPK) signaling and the enhancement of the nitric oxide/cGMP pathway [57,58]. Moreover, data revealed that resveratrol exerts its effect toward lipooxygenase inhibiting the TxB2, a stable derivative of TxA2, involved in platelet aggregation and inflammatory processes [59]. Conversely, its inhibition of both inducible and constitutive COX-2 in the vascular endothelial cells was less selective compared to COX-1, leading to prostacyclin blockade and thus contrasting its vasodilatory and antiplatelet activities [58]. Specifically, the in vivo vasorelaxant activity of resveratrol was attributed to the capability to trigger the $\mathrm{Ca}^{2+}$-activated potassium $\left(\mathrm{K}_{\mathrm{Ca}}\right)$ channels and to stimulate both endothelium nitric oxide synthase (eNOS) and inducible nitric oxide synthase (iNOS) expression [60,61]. The vasorelaxing action of resveratrol is also carried out through the inhibition of both L-type $\mathrm{Ca}^{2+}$ channel and $\mathrm{Ca}^{2+}$ calmodulin cyclic nucleotide phosphodiesterase 1C (PDE1C) and the consequent decrease of contractile response of vascular smooth muscle cells (VSMCs). Resveratrol leads to lower contractile strength via eNOS induction and via limiting the intracellular $\mathrm{Ca}^{2+}$ release in VSMC, which reflects hypertension control [62]. Another potential target of resveratrol, with which it exerts anti-inflammatory activity, is represented by stimulation of Sirtuin-1 (Sirt-1) that impairs the inflammatory signal cascade of toll-like receptor 4/nuclear factor k-light-chain enhancer of activated B cells/signal transducer and activator transcription (TLR4/NF-KB/STAT), thus reducing the production of cytokines such as tumor necrosis factor $\alpha$ (TNF- $\alpha$ ), interleukin-6 (IL-6), interleukin $1 \beta$ (IL-1 $\beta$ ) and monocyte chemoattractant protein-1 (MCP-1) or macrophage/mast cell-derived factors [63]. Particularly, resveratrol and its analogues were able to improve serum level of Sirt- 1 with consequent preservation of endothelial homeostasis through the inhibition of TLR4/NF-kB/STAT pathways and related pro-inflammatory cytokines $[63,64]$. High levels of Sirt-1 were found to influence the expression of endothelial nitric oxide synthase (eNOS) responsible for producing nitric oxide (NO), a key player in the increase of vascular perfusion $[60,61]$. Several studies reported the capability of resveratrol in increasing the serum levels of adiponectin. Considering that this adipocyte-specific protein is significantly reduced in models of obesity and insulin resistance, and that its reduction is remarkably related to an increased risk of atherosclerosis, it is plausible that resveratrol could exert anti-atherosclerotic effects by increasing adiponectin serum levels [62,65-67]. High levels of adiponectin were indeed correlated with the inhibition of NF- $\mathrm{kB}$ signal and thus with the reduction of pro-inflammatory factors, preventing monocyte adhesion on vascular endothelium, the first process for atherosclerotic plaque formation [65]. Chronic low-grade inflammation, the formation of atherosclerotic plaques and platelet aggregation are, together with hypertension and reduced sensitivity to glucose, essential conditions for the development of the so-called metabolic syndrome that resveratrol has been shown to improve. Cardiovascular diseases (CVDs) are very often accompanied by obesity and impaired glucose metabolism. It was documented that resveratrol administration is able to decrease the plasma levels of glucose and glycated hemoglobin $(\mathrm{HbA1c})$. The probable mechanism underlying the decrease of these markers was the activation of peroxisome proliferator-activated receptor gamma coactivator 1-alpha (PGC-1 $\alpha$ ) via Sirt-1 and the derived mitochondria biogenesis regulation. Insulin resistance indeed was found to be correlated to decremented PGC-1 $\alpha$ activity [68-70]. Moreover, the positive effect of resveratrol on glucose levels was expressed through the activation of adenosine $5^{\prime}$ monophosphate-activated protein kinase (AMPK), a kinase closely interlinked to mitochondrial functions and metabolism and, thus, of type 2 diabetes mellitus (T2DM) development [68-70]. The abovementioned inhibition of 
NF- $\mathrm{kB}$ signaling by resveratrol was also considered a plausible anti-diabetic mechanism. The NF- $\mathrm{B}$ pathway, indeed, was upregulated in T2DM, and the consequent IL-6 production led to cell insulin resistance. This condition resulted in both chronic high glucose plasma levels and high glycation products. These latter trigger the expression of glycation end-product receptors that, in turn, stimulate the NF- $\mathrm{KB}$ signaling cascade [71-74]. In recent years, resveratrol has arisen interest for its antitumor activity, and the underlying mechanisms are multiple and still under analysis. It demonstrated a double capability to both protect normal cells from radiation/chemotherapy damage and coadjuvate tumor cell suppression. Resveratrol was documented to interact with the complex tumor microenvironment network, a precondition for tumor growth, progression and metastasis. Particularly it was seen to play a key role in the apoptotic signaling of the tumor cell through direct stimulation of caspases cascade and the inhibition of the anti-apoptotic pathways such as PTEN/PI3K/AKT, Sirt-1, AMPK/YAP, NF- $\mathrm{KB}$ and STAT3 that contribute to tumor cell immortality [75-80]. The anti-proliferative property of resveratrol occurs with the enhancement of p21 and thus p53 activity. P21 is a strong inhibitor of Cyclin-Dependent Kinases and is able to link to the CDK2-CDK4 complex, responsible for the cell cycle progression from G1 to S phase. Such a bond allows p53 to definitely block the cell replication phase [81-83]. It emerged that resveratrol is able to induce the tumor cell cycle blockade also via inhibition of other intracellular signals such as Wnt/ $\beta$-catenin, Hippo-YAP and Hedgehog that synergistically concur to tumor development, invasion and metastasis [54,84-86]. These pathways are also implicated in epithelial mesenchymal transition (EMT), a process conferring epithelial cells with mesenchymal characteristics necessary for tumor invasion. Furthermore, data demonstrated that the inhibition of PI3K/AKT, Hippo-YAP, activating protein (AP-1), Hedgehog and in particular HIF-1 $\alpha$ contributed to reduce angiogenesis of new blood vessels required for tumor growth [50-52,54,87,88].

Table 1. Resveratrol main effects.

\begin{tabular}{|c|c|c|}
\hline Effect & Pathway & Reference \\
\hline \multirow[t]{4}{*}{ Antioxidant } & Copper-chelant & {$[44,45,49]$} \\
\hline & Activation p38-MAPK & [52] \\
\hline & Inhibition QR2 & [48] \\
\hline & Up-regulation SOD & [47] \\
\hline \multirow[t]{5}{*}{ Anti-Inflammatory } & Inhibition $\mathrm{COX}_{1}$ & {$[55,56,58]$} \\
\hline & Inhibition $\mathrm{COX}_{2}$ & {$[55,56,58]$} \\
\hline & Blocked TxA 2 & {$[57,58]$} \\
\hline & Blocked MAPK & {$[57,58]$} \\
\hline & Activation Sirt-1 $\rightarrow \uparrow$ TLR4/NF-kB/STAT; $\downarrow$ TNF- $\alpha / \mathrm{IL}-6 / \mathrm{IL}-1 \beta$ & {$[63,64]$} \\
\hline Vasodilatation & Activation $\mathrm{K}^{+}$channel $\mathrm{Ca}^{2+} \rightarrow \uparrow \mathrm{eNOS}, \uparrow \mathrm{eNOS}$ & [60-62] \\
\hline \multirow{2}{*}{$\begin{array}{l}\text { Metabolic Disorder } \\
\text { (CVD/T2DM/Obesity) }\end{array}$} & Activation Sirt-1 $\rightarrow$ Activation PGC- $1_{\alpha} \rightarrow \downarrow$ plasma levels glucose \& glycated & [68-70] \\
\hline & Activation AMPK & [68-70] \\
\hline \multirow[t]{5}{*}{ Cancer } & Inhibition Sirt-1/PTEN/PI3K/AKT & [75-80] \\
\hline & Upregulation p21/p53 & [81-83] \\
\hline & Inhibition AMPK/YAP & {$[54,84-86]$} \\
\hline & Inhibition NF-кB/STAT3 & [78] \\
\hline & Downregulation HIF- $1 \alpha$ & {$[54]$} \\
\hline
\end{tabular}

\section{Resveratrol in Cardio-Oncology}

As outlined above, several foods are naturally rich in resveratrol, like nuts, grapes, apples, red fruits, black olives, capers, brown or red rice and others [89]. Notably, they are very common in the Mediterranean diet which has demonstrated to have significant anti-inflammatory, anti-obesity and 
cardioprotective properties [90]. Being an extremely reactive molecule as well as capable to interact both with cytoplasmic and nuclear proteins $[89,90]$ in human cells, resveratrol has been studied over the years as complementary and alternative medicine (CAM) for the therapy of cardiovascular diseases like myocardial ischemia [90,91], myocarditis [92], cardiac hypertrophy and heart failure [93,94]. The main mechanisms underlying its beneficial effects are based on its anti-oxidative and anti-inflammatory properties [89] as well as its improvements of calcium homeostasis in cardiomyocytes and reduction of cardiac fibrosis [95].

Preclinical and updated clinical evidence on the effects of resveratrol in cardiology is presented, with interesting implications in the cardio-oncological field, considering that some cardiac targets share common tumor targets, tightening on its possible use as a cardioprotective agent in cardio-oncology. Resveratrol has demonstrated to significantly reduce the oxidation of low-density lipoprotein (Ox-LDL), which is the key initiation point of atherosclerosis as well as a source of survival and resistance in breast, colon and prostate cancer cells through the involvement of $\beta$-catenin, cMyc, NF- $\mathrm{kB}$, STAT1, STAT3 and other oncogenes [96-98]. Moreover, resveratrol has shown to reduce the risk of thrombosis through inhibition of platelet aggregation in preclinical models [99], Considering that venous thromboembolism is a major health problem among cancer patients [100], associated with high rates of mortality and morbidity, the possible use of resveratrol in this category of patients could be interesting.

Other data indicating the cardioprotective nature of resveratrol include the risk of atherogenesis. In preclinical studies, oral administration of resveratrol at $4 \mathrm{mg} / \mathrm{kg} /$ day reduced significantly the proliferation of smooth muscle cells, hyperplasia of endothelial vessels as well as the secretion of pro-inflammatory cytokines involved in the atherogenesis process [101]. Notably, another cardiovascular outcome associated with the administration of resveratrol in preclinical studies is the reduction of intimal proliferation index (ratio of intimal to (intimal + medial) area) of 45-50\% compared to control animals with a significant reduction of $\alpha$-actin expression in intima [102]. The main mediators of these effects are p53, heat shock protein HSP27, quinone reductases as well as nitric oxide [102]. Considering that several cancer therapies like androgen deprivation therapy are conceived to indirectly contribute to the development of hyperglycemia, dyslipidemia and metabolic syndrome, which are well-established causal risk factors of atherosclerosis [103,104], the use of resveratrol in this category of patients could be a therapeutic window of interest in the cardio-oncological field.

Another critical side effect seen in cancer patients is anthracycline-induced cardiotoxicity $[105,106]$. As recently summarized, cardiac event rates on doxorubicin therapy are $7 \%, 18 \%$ and $65 \%$ at cumulative doses of 150, 350 and $550 \mathrm{mg} / \mathrm{m}^{2}$, respectively [107]. Anthracycline chemotherapy was associated with an adjusted hazard ratio of 1.26 for development of congestive cardiac failure in 43,000 women (aged 66-70 years) with breast cancer over a median period of 53 months [107]. It is known that the mechanisms of doxorubicin-induced cardiotoxicity are mainly mediated by the involvement of oxidative stress as well as several pro-inflammatory mediators [108,109]. Resveratrol combined with doxorubicin significantly reduces the cardiotoxic phenomena in preclinical trials with the involvement of E2F1/AMPK $\alpha 2$ and E2F1/mTORC1 pathways [110]. Notably, resveratrol reduces apoptosis and necrosis of cardiac cells and improves calcium homeostasis, reducing also cytokine and collagen fibers, leading to a decrease of fibrosis in the myocardium [111]. The main mediators of these effects are the upregulation of Sirt-1, the reduction of transforming growth factor-beta and pSMAD3/SMAD3 [111]. In another recent study, co-administration of doxorubicin and resveratrol in mouse led to a reduction of both cardiac p38 MAPK activation and hypertrophy in response to Ang II-induced hypertension [112].

Clinical trials with resveratrol administration and cardiovascular outcomes are also described. First, resveratrol orally administered at $270 \mathrm{mg}$ month in obese patients enhanced the endothelial functions with a significant increase of flow-mediated dilatation of the brachial artery [113]. Second, a similar study demonstrated that resveratrol improved levels of glucose and triglycerides [114]. Another trial involving patients with stable coronary artery disease demonstrated that resveratrol at $10 \mathrm{mg}$ per day for 3 months improved left ventricle diastolic functions [115], and in a comparable study, double doses for 2 months led to a reduction of b-type natriuretic peptide (BNP) in patients with angina 
pectoris, demonstrating cardioprotective effects [116]. At present there are similar ongoing clinical trials based on the oral administration of resveratrol in patients suffering from heart failure with strong clinical expectations such as the improvement of the left ventricular ejection fraction, the reduction of inflammatory markers and indicators of myocardial damage [94]. The overall picture described herein places resveratrol as a potential cardioprotective tool in non-cancer as well as in cancer patients.

\section{Metabolic Effect and Cancer-Drug Interactions}

Recently, resveratrol has been shown to implement antineoplastic activities due to repression of neoplastic carcinogens by inhibiting phase I enzymes and synergistically by induction of phase II metabolic enzymes [117]. Resveratrol has demonstrated to interact with several antioxidant and anti-inflammatory agents. It supports an anticancer environment, through the inhibition/activation of the metabolic phase I enzymes, and induction/conjugation of phase II enzymes [118,119]. However, resveratrol supplementation would result in less activation of procarcinogens such as benzo-pyrenes. Phase I metabolism of xenobiotics like pharmaceutical drugs, phytochemicals, environmental pollutants and other endogenous compounds like hormones is accomplished mainly by the cytochrome P450 (CYP) family enzymes (Table 2).

It has been shown that resveratrol in preclinical studies inhibits the activity of CYP1A enzymes [120,121], and in particular it inactivates CYP1A2 in a microsomal mechanism-based assay. Nonetheless, resveratrol metabolites were likely responsible for the observed inhibitory activity [122]. A subsequent study found that a metabolite called RS3 did not inhibit CYP1A2 in cell cultures [123]. Another metabolite called piceatannol has been shown to inhibit CYP1A activity to an extent similar to that of resveratrol in rat hepatic microsomes and could affect its interactions with CYP1A enzymes. Since resveratrol induced CYP1A2 activity (evaluated in preclinical studies), the evidence from in vitro models demonstrated the inhibition of CYP1A1 and CYP1A2 by resveratrol. In an early clinical phase I study, in half the participants at $1 \mathrm{~g}$ daily resveratrol, $100 \mathrm{mg}$ caffeine was added for 4 weeks, and the results were indicative of CYP1A2 induction [122,123]. The observed difference between this clinical observation and preclinical in vitro studies could be attributed to the indirect assessment of CYP1A2 activity, or to resveratrol metabolism. Since CYP1B1 is involved in the metabolism of catechol estrogen and the formation of a toxicologically active metabolite, 4-hydroxyestradiol, the inhibition of CYP1B1 is an attractive target for hormonally driven cancers such as breast. It is documented that $5 \mu \mathrm{mol} / \mathrm{L}$ resveratrol was able to reduce the formation 17b-estradiol through the inhibition of CYP1B1 in human mammary epithelial cells [124]. In overweight and obese postmenopausal women, $1 \mathrm{~g} /$ daily resveratrol for 12 weeks also had a favourable effect on estrogen metabolism [125]. Supplementation diet containing resveratrol for 12 weeks evidenced high anticoagulant levels by warfarin in a murine model, suggesting the inhibition of CYP2C9 [126]. As monitored in humans, a dose of $1 \mathrm{~g}$ daily resveratrol for 4 weeks was shown to inhibit CYP2C9 by 2.71-fold using losartan as a probe drug [122].

Table 2. Metabolic effects and cancer-drug interactions.

\begin{tabular}{|c|c|c|c|c|}
\hline $\begin{array}{l}\text { Metabolic Enzyme } \\
\text { (Direct Effect) }\end{array}$ & $\begin{array}{c}\text { Documented Interaction. } \\
\text { Plasma Levels: } \\
\text { (H) Higher } \\
\text { (L) Lower Dosage }\end{array}$ & $\begin{array}{l}\text { Potential Cancer } \\
\text { Drug Interaction }\end{array}$ & Pharmacogenomic Test & $\begin{array}{c}\text { Final Consideration } \\
\text { [Reference] }\end{array}$ \\
\hline $\begin{array}{l}\text { CYP1A1 } \\
\text { (Inhibition) }\end{array}$ & $\begin{array}{c}\text { Testosterone \# } \\
\text { Caffeine (in human) } \\
\text { Phenacetin }\end{array}$ & Bendamustine & $\begin{array}{c}\text { CYP1A2*F 5'UTR } \\
-163 \mathrm{C}>\mathrm{A} \text { rs7625551 }\end{array}$ & [123] \\
\hline $\begin{array}{c}\text { CYP1B1 } \\
\text { (Inhibition) }\end{array}$ & $\begin{array}{l}\text { (L) Cathecol estrogens } \\
\text { (anti-breast cancer activity } \\
\text { of resveratrol) \# }\end{array}$ & ND & ND & $\begin{array}{c}1 \mathrm{~g} / \text { day for } 12 \text { weeks had } \\
\text { a favorable effect in } \\
\text { post-menopausal women } \\
{[124]}\end{array}$ \\
\hline $\begin{array}{c}\text { CYP2B6 } \\
\text { (Inhibition) }\end{array}$ & ND & Cyclophosphamide & ND & [127] \\
\hline
\end{tabular}


Table 2. Cont.

\begin{tabular}{|c|c|c|c|c|}
\hline $\begin{array}{l}\text { Metabolic Enzyme } \\
\text { (Direct Effect) }\end{array}$ & $\begin{array}{c}\text { Documented Interaction. } \\
\text { Plasma Levels: } \\
\text { (H) Higher } \\
\text { (L) Lower Dosage }\end{array}$ & $\begin{array}{l}\text { Potential Cancer } \\
\text { Drug Interaction }\end{array}$ & Pharmacogenomic Test & $\begin{array}{l}\text { Final Consideration } \\
\text { [Reference] }\end{array}$ \\
\hline $\begin{array}{l}\text { CYP2C9 } \\
\text { (Inhibition) }\end{array}$ & (H) Warfarin \# & ND & $\begin{array}{c}\text { CYP2C9*2 430C>T R144C. } \\
\text { rs } 1799853 \\
C Y P 2 c 9 * 31075 \mathrm{~A}>\mathrm{C} \text { I359L } \\
\text { rs } 1057910\end{array}$ & $\begin{array}{c}1 \text { g daily resveratrol } \\
\text { inhibited CYP2C9 by } \\
2.71 \text {-fold } \\
{[126]}\end{array}$ \\
\hline $\begin{array}{c}\text { CYP2D6 } \\
\text { (Low inhibition) }\end{array}$ & (L) dextromethorphan \$ & Tamoxifen & $\begin{array}{c}\text { CYP2D6*3 2459delA } \\
\text { frameshift rs35742686 } \\
\text { CYP2D } 6^{*} 41846 \mathrm{G}>\mathrm{A} \\
\text { splicing rs3892097 } \\
\text { CYP2D6*10 100C>T P35S } \\
\text { rs1065852 } \\
\text { CYP2D6*XN copy } \\
\text { number variation }\end{array}$ & $\begin{array}{c}\text { Probable low activation } \\
\text { of tamoxifen in the active } \\
\text { metabolite endoxifen } \\
\text { [122] }\end{array}$ \\
\hline $\begin{array}{c}\text { CYP2C19 } \\
\text { (Moderate Inhibition) }\end{array}$ & (H) Pantoprazole \$ & ND & $\begin{array}{c}\text { CYP2C19*17 -806C >T } \\
\text { 5'UTR rs12248560 }\end{array}$ & {$[121]$} \\
\hline $\begin{array}{c}\text { CYP3A4 } \\
\text { (Inhibition) }\end{array}$ & $\begin{array}{c}\text { (H) Nicardipine \$ } \\
(\mathrm{H}) \text { diltiazem } \$ \\
(\mathrm{H}) \text { Carbamazepine \$ }\end{array}$ & $\begin{array}{l}\text { Imatinib } \\
\text { Docetaxel }\end{array}$ & $\begin{array}{c}\text { CYP3A4*22 15389C>T } \\
\text { 5"UTR rs35599367 }\end{array}$ & {$[125,128]$} \\
\hline $\begin{array}{c}\text { GST } \\
\text { (Induction) }\end{array}$ & $\begin{array}{l}\text { (L) nitrosamines and } \\
\text { polycyclic aromatic } \\
\text { Hydrocarbon \# }\end{array}$ & $(\mathrm{H})$ platin derivates & GSTP1 Iso105Val & [129] \\
\hline $\begin{array}{c}\text { NQO1 } \\
\text { (Induction) }\end{array}$ & $\begin{array}{l}\text { (L) Estrogens by } \\
\text { inactivation by } \\
\text { catechol-O-methyl } \\
\text { transferase \# }\end{array}$ & ND & ND & {$[130,131]$} \\
\hline
\end{tabular}

Resveratrol has demonstrated moderate inhibition of CYP2C19 in microsome models and the human recombinant form [121,132]. In cell line models, inhibition of CYP2D6 by resveratrol had low significance (50\% inhibitory concentration $\mathrm{IC}_{50}$ of $\left.87.9 \mathrm{~mol} / \mathrm{L}\right)$ for resveratrol and its metabolites [127]. In humans administered $1 \mathrm{~g} /$ day resveratrol for 4 weeks, however, CYP2D6 activity decreased by 1.7-fold (dextromethorphan as probe), and warnings are suggested in combined treatments with tamoxifen $[122,126]$. Therefore, when considering resveratrol supplementation, it is necessary to predict potential interactions with CYP3A4 to ensure the safety of patients receiving chemotherapeutics. A pharmacokinetic study in 12 healthy males was conducted to determine the effect of resveratrol pretreatment on the pharmacokinetics of carbamazepine and on the CYP3A4 enzyme activity. Compared to controls, a single $500 \mathrm{mg}$ dose of resveratrol administered once daily for 10 days prior to a single dose of carbamazepine $200 \mathrm{mg}$ significantly increased maximal drug concentration (by $46.2 \%$ ), area under the curve (by $37.1 \%$ ) and half-life (by 22.8\%) of carbamazepine and significantly decreased apparent oral clearance (by 33.1\%) and apparent volume of distribution (by 19.3\%). However, the time to reach maximum drug concentration and elimination rate constant had not significantly changed. Additionally, carbamazepine metabolite/parent ratios of $\mathrm{C}_{\max }$ and AUC (Area Under the Curve) had also significantly decreased [128]. Several experiments strongly support an induction effect of resveratrol of several phase II enzymes including glutathione S-transferase (GST), nicotinamide hydrogenase (NADH), UDP-glucuronosyl transferase, (UGT) and catechol-O-methyl transferase (COMT). Resveratrol may facilitate the removal of carcinogens from the body. With regard to the association between GST induction and reduced cancer risk, in humans $1 \mathrm{~g}$ /day of resveratrol for 4 weeks induced GST activity among individuals, but the overall effect was not significant [122,129]. The induction of NQO1 gene, encoding for $\mathrm{NAD}(\mathrm{P}) \mathrm{H}$ dehydrogenase (quinine) enzyme, by resveratrol could have significant implications on breast cancer prevention. Estrogens were transformed into catechols and further oxidized into ortho-quinones, which react with DNA to form adducts [130]. By inducing NQO1, resveratrol may facilitate the reduction in semi-quinones to catechols and subsequent inactivation by COMT $[130,131]$. In a clinical trial, $1 \mathrm{~g} /$ day resveratrol for 4 weeks significantly increased bilirubin clearance among subjects with low baseline UGT1A1 activity; however, resveratrol intervention had a minimal effect on overall bilirubin clearance [122]. Nonetheless, evidence of nutrient-drug interactions suggests that this mechanism may still contribute to resveratrol's overall anticancer properties. This evidence also shows that resveratrol interactions with drug metabolism are significant 
enough to warrant further investigation before its clinical recommendation. Although in vitro studies provide a controlled environment for precise quantification of resveratrol effect on phase I and II metabolism, they fail to capture the activity of resveratrol metabolites, which may have important clinical effects. Provided with the limited evidence available, we have attempted to consider the activity of resveratrol's sulfated and glucuronidated metabolites to evaluate the translatability of certain animal models to humans.

\section{Resveratrol and Cancer Evidence}

With almost 10 million deaths per year worldwide, cancer is a major public health problem, and it has become the second leading cause of death in Western countries [133]. Surgery, antiblastic chemotherapy (CT), target therapy (TT), immunotherapy and radiotherapy (RT) are the most common treatments for cancer. Antiblastic CT, TT, immunotherapy and RT are used as primary treatment approaches in most cancer patients and play vital roles in cancer treatment because many patients are diagnosed at advanced stages, compromising the option of surgery treatment [134]. However, more tumors have become resistant to CT, TT, immunotherapy and RT, which has become a major problem in cancer therapy. Furthermore, complications emerge when cancer cells develop chemoresistance and radioresistance via multiple mechanisms, and the CT agents and RT often cause adverse events [135]. Therefore, we need to identify a new strategy or new therapeutic agent that can overcome chemoresistance and radioresistance. A large number of natural products are considered to be effective anticancer drugs [136]. Most of them are found in fruit and vegetables, such as polyphenols and resveratrol [137]. These compounds have multiple effects in several chronic disease treatments, including cancer $[136,137]$. Resveratrol has been shown to regulate cellular growth in many human cancer cell lines [138]. Especially, its role in inducing growth inhibition, cell cycle arrest and apoptosis suggested the possibility to use resveratrol to prevent cancer (Figure 6) $[139,140]$. A number of studies highlighted that this cell-growth modulating effect is both dose- and time-dependent [141,142]. However, the exact mechanism of these actions is not fully understood [136,142]. A high concentration of radical oxygen species (ROS) is found in cancer cells. ROS are a cornerstone in cancer onset and progression through the promotion of cell growth, immortalization and aberrant inhibition of locomotion and proliferation [143]. Resveratrol carries out its antioxidant properties through several mechanisms $[143,144]$. Especially, resveratrol modulates antioxidant enzymes such as superoxide dismutase, catalase and glutathione peroxidase [144]. Therefore, it induces cancer cell apoptosis by accumulation of hydrogen peroxide [144]. Resveratrol can also downregulate hypoxia-inducible factor- $1 \alpha$ (HIF- $1 \alpha$ ) accumulation, leading to the suppression of fluorodeoxyglucose (F-FDG) uptake from metabolically active cells and glycolysis $[54,145]$.

The tumor microenvironment (TME) is defined as the totality of normal cells, molecules and blood vessels surrounding and feeding each cancer cell [146]. TME cells are stromal cells, immune-inflammatory cells and vascular endothelial cells. Their interactions with each other and with the cancer cells through the secretion of cytokines and chemokines play a fundamental role in tumor initiation and progression [146]. As a matter of fact, a healthy TME protects against tumorigenesis [147]. On the contrary, disorders of the TME increase the levels of inflammatory cytokines, such as tumor necrosis factor $\alpha$ (TNF- $\alpha$ ), promoting tumorigenesis through cell immortalization [147]. Moreover, TME governs chemo- and radio-resistance [148]. Therefore, targeting TME to defy cancer could be a winning strategy, both because of its involvement in tumorigenesis and the fact that it is less prone to mutate and rapidly cause metastatic events [148]. Cancer is characterized by a chronic inflammatory state, derived from the activation of both the immune and adaptive immune system cells present within the TME [146]. Thanks to its action on antioxidant enzymes and HIF-1 $\alpha$, among other effects, resveratrol has been proposed as a possible agent able to downregulate chronic inflammation in TME (Figure 7) [149]. In fact, resveratrol downregulates the production of inflammatory cytokines and increases the release of anti-inflammatory mediators by inhibiting AP-1 and NF- $\mathrm{KB}$ [150]. TME is a hypoxic environment, created by a rapid cancer cell growth and dysregulation of angiogenesis [149]. 
HIF- $1 \alpha$, a transcription factor regulating the expression of more than a hundred genes, is overly expressed during hypoxia, promoting more aggressive behaviors of the cancer such as chemo-resistance and metastatic spread [54,149]. As previously mentioned, resveratrol is able to modulate the expression of HIF- $1 \alpha$, thus reducing the fitness of TME to the expansion of the tumor [149]. Modulation of HIF- $1 \alpha$ leads to another important effect of resveratrol as an anti-tumor agent. Through downregulation of HIF-1 $\alpha$ and increased expression of thrombospondin-1, resveratrol acts as an anti-angiogenic drug [149]. Resveratrol was also demonstrated to be able to interfere with the activation of some immune cells through the inhibition of the proliferation of both $\mathrm{T}$ and $\mathrm{B}$ lymphocytes and the downregulation of the expression of cluster of differentiation CD28 and CD80 on T-lymphocytes and macrophages, respectively [151]. A particular subset of macrophages, named tumor-associated macrophages (TAMs), are activated by cancer cells and promote the production of inflammatory cytokines through a STAT3 pathway. Resveratrol is able to decrease STAT3 activation in cancer [152]. In addition, resveratrol modulates the PI3K pathway in cancer cells, which downregulates CD8+ cytotoxic T cell activity. Therefore, by inhibiting PI3K, resveratrol enhances anti-cancer immunity [75].

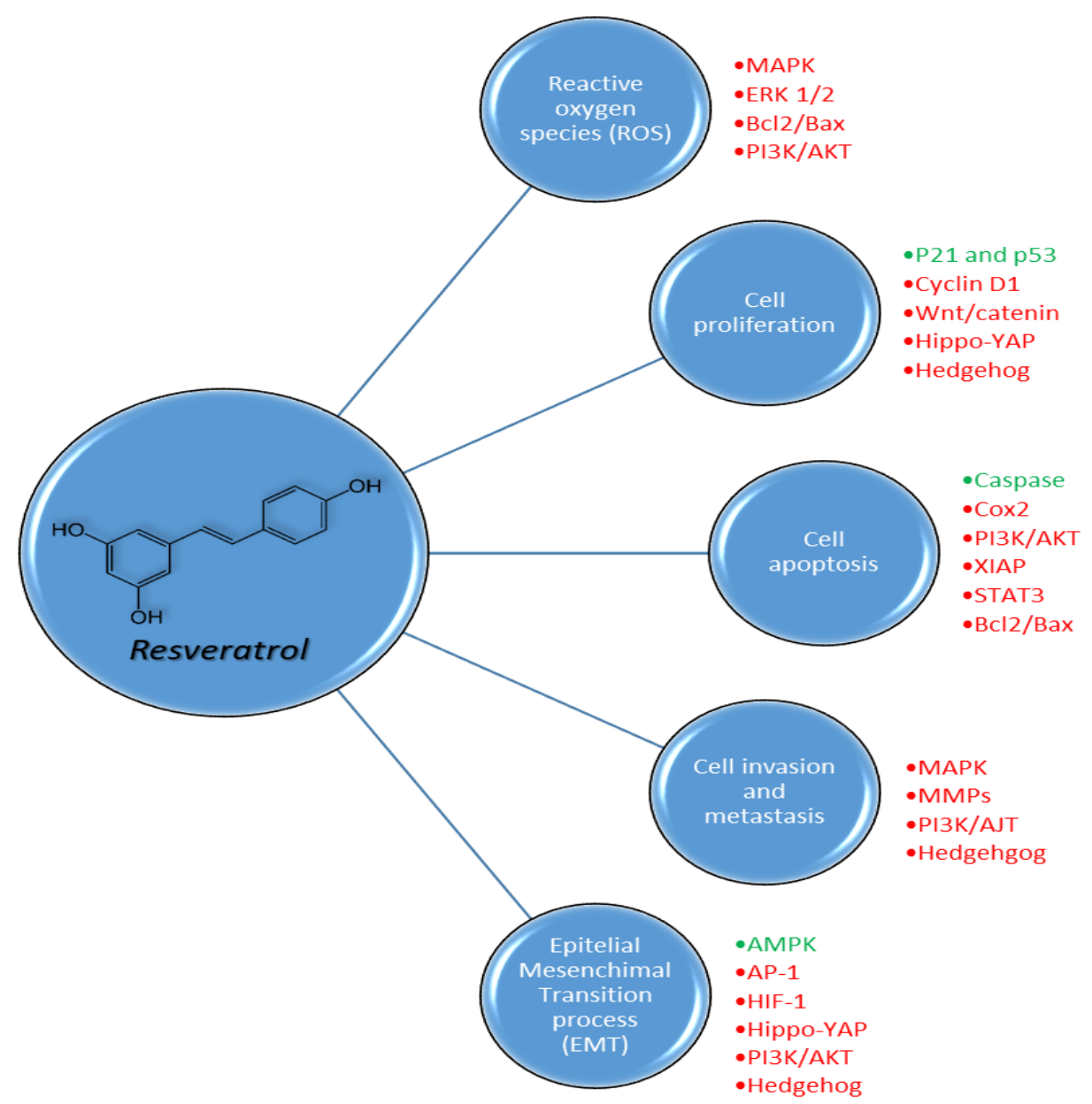

Figure 6. Pleiotropic biochemical effects of resveratrol on reactive oxygen species (ROS), cell proliferation, cell apoptosis, cell invasion and metastasis and epithelial mesenchymal transition processes in cancer cells through the activation (green) or inhibition (red) of different pathways. 

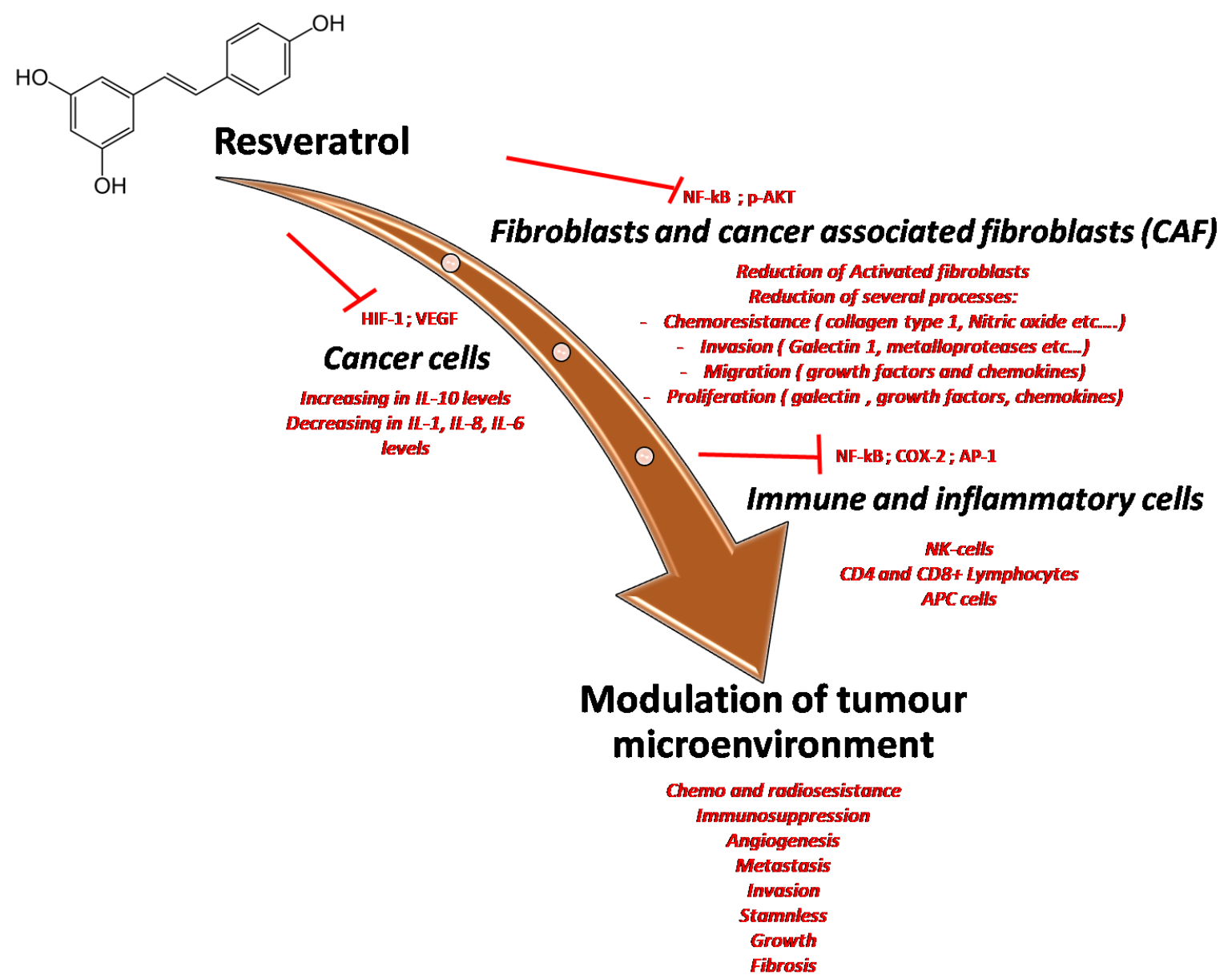

Figure 7. Multiple effects of resveratrol on the tumor microenvironment through the inhibition of many pro-inflammatory mediators and cytokines involved in cancer cell survival, in cancer-associated fibroblast activation and modulation of immune cells resident in tumor tissue.

\section{Conclusion and Perspectives}

An increasing number of clinical trials are supporting the benefits of resveratrol in the treatment of chronic diseases, although its use in clinical practice remains very limited. In order to unlock the therapeutic potential of resveratrol and its derivatives, further investigations are warranted aiming to enhance its pharmacokinetic profile through testing new, innovative formulations. Moreover, future clinical trials should investigate the drug interaction between anticancer agents, resveratrol and enzymes activity, particularly focusing on CYP2C9, CYP2C19 (phase I enzyme), GSTP1 and UGT (phase II enzyme) [153]. Promisingly, evaluation of individual metabolic profiles by pharmacogenetic tests should be accurate to perform a personalized therapy in cancer "frail patients" (i.e., HIV) where supplementation of resveratrol allows the reduction of antineoplastic drug dosages $[154,155]$.

Funding: This work was partially funded by the "Ricerca Corrente" grant from the Italian Ministry of Health.

Acknowledgments: The authors are grateful to Sara Colò, translator at the Experimental and Clinical Pharmacology Unit of CRO in Aviano, for editing the manuscript. Special thanks to "Ministero della Salute Ricerca Corrente".

Conflicts of Interest: The authors declare no competing financial interests. 


\section{References}

1. Burns, J.; Yokota, T.; Ashihara, H.; Lean, M.E.J.; Crozier, A. Plant foods and herbal sources of resveratrol. J. Agric. Food Chem. 2002, 50, 3337-3340. [CrossRef]

2. Shrikanta, A.; Kumar, A.; Govindaswamy, V. Resveratrol content and antioxidant properties of underutilized fruits. J. Food Sci. Technol. 2015, 52, 383-390. [CrossRef]

3. Akinwumi, B.C.; Bordun, K.-A.M.; Anderson, H.D. Biological Activities of Stilbenoids. Int. J. Mol. Sci. 2018, 19, 792. [CrossRef]

4. Pezzuto, J.M. Resveratrol: Twenty Years of Growth, Development and Controversy. Biomol. Ther. 2019, 27, 1-14. [CrossRef]

5. Wang, F.; Chatterjee, S. Dominant Carbons in trans- and cis-Resveratrol Isomerization. J. Phys. Chem. B 2017, 121, 4745-4755. [CrossRef]

6. Iuga, C.; Alvarez-Idaboy, J.R.; Russo, N. Antioxidant activity of trans-resveratrol toward hydroxyl and hydroperoxyl radicals: A quantum chemical and computational kinetics study. J. Org. Chem. 2012, 77, 3868-3877. [CrossRef]

7. Stivala, L.A.; Savio, M.; Carafoli, F.; Perucca, P.; Bianchi, L.; Maga, G.; Forti, L.; Pagnoni, U.M.; Albini, A.; Prosperi, E.; et al. Specific structural determinants are responsible for the antioxidant activity and the cell cycle effects of resveratrol. J. Biol. Chem. 2001, 276, 22586-22594. [CrossRef]

8. O'Neil, M.J. The Merck Index-An Encyclopedia of Chemicals, Drugs, and Biologicals, 15th ed.; Royal Society of Chemistry: London, UK, 2013; ISBN 978-1-84973-670-1.

9. Zupančič, Š.; Lavrič, Z.; Kristl, J. Stability and solubility of trans-resveratrol are strongly influenced by $\mathrm{pH}$ and temperature. Eur. J. Pharm. Biopharm. 2015, 93, 196-204. [CrossRef]

10. Takaoka, M. Resveratrol, a new phenolic compound, from Veratrum grandiflorum. J. Chem. Soc. Japan 1939, 60, 1090-1100.

11. Arichi, H.; Kimura, Y.; Okuda, H.; Baba, K.; Kozawa, M.; Arichi, S. Effects of stilbene components of the roots of Polygonum cuspidatum Sieb. et Zucc. on lipid metabolism. Chem. Pharm. Bull. (Tokyo) 1982, 30, 1766-1770. [CrossRef]

12. Azorín-Ortuño, M.; Yañéz-Gascón, M.J.; Pallarés, F.J.; Vallejo, F.; Larrosa, M.; García-Conesa, M.T.; Tomás-Barberán, F.; Espín, J.C. Pharmacokinetic study of trans-resveratrol in adult pigs. J. Agric. Food Chem. 2010, 58, 11165-11171. [CrossRef]

13. Scott, E.; Steward, W.P.; Gescher, A.J.; Brown, K. Resveratrol in human cancer chemoprevention-choosing the "right" dose. Mol. Nutr. Food Res. 2012, 56, 7-13. [CrossRef] [PubMed]

14. Walle, T.; Hsieh, F.; DeLegge, M.H.; Oatis, J.E.; Walle, U.K. High absorption but very low bioavailability of oral resveratrol in humans. Drug Metab. Dispos. Biol. Fate Chem. 2004, 32, 1377-1382. [CrossRef] [PubMed]

15. Soleas, G.J.; Angelini, M.; Grass, L.; Diamandis, E.P.; Goldberg, D.M. Absorption of trans-resveratrol in rats. Methods Enzymol. 2001, 335, 145-154. [PubMed]

16. Abd El-Mohsen, M.; Bayele, H.; Kuhnle, G.; Gibson, G.; Debnam, E.; Kaila Srai, S.; Rice-Evans, C.; Spencer, J.P.E. Distribution of $[3 \mathrm{H}]$ trans-resveratrol in rat tissues following oral administration. Br. J. Nutr. 2006, 96, 62-70. [CrossRef] [PubMed]

17. Henry, C.; Vitrac, X.; Decendit, A.; Ennamany, R.; Krisa, S.; Mérillon, J.-M. Cellular uptake and efflux of trans-piceid and its aglycone trans-resveratrol on the apical membrane of human intestinal Caco-2 cells. J. Agric. Food Chem. 2005, 53, 798-803. [CrossRef] [PubMed]

18. Henry-Vitrac, C.; Desmoulière, A.; Girard, D.; Mérillon, J.-M.; Krisa, S. Transport, deglycosylation, and metabolism of trans-piceid by small intestinal epithelial cells. Eur. J. Nutr. 2006, 45, 376-382. [CrossRef]

19. Rotches-Ribalta, M.; Andres-Lacueva, C.; Estruch, R.; Escribano, E.; Urpi-Sarda, M. Pharmacokinetics of resveratrol metabolic profile in healthy humans after moderate consumption of red wine and grape extract tablets. Pharmacol. Res. 2012, 66, 375-382. [CrossRef]

20. Vitrac, X.; Desmoulière, A.; Brouillaud, B.; Krisa, S.; Deffieux, G.; Barthe, N.; Rosenbaum, J.; Mérillon, J.M. Distribution of [14C]-trans-resveratrol, a cancer chemopreventive polyphenol, in mouse tissues after oral administration. Life Sci. 2003, 72, 2219-2233. [CrossRef]

21. Menet, M.-C.; Baron, S.; Taghi, M.; Diestra, R.; Dargère, D.; Laprévote, O.; Nivet-Antoine, V.; Beaudeux, J.-L.; Bédarida, T.; Cottart, C.-H. Distribution of trans-resveratrol and its metabolites after acute or sustained administration in mouse heart, brain, and liver. Mol. Nutr. Food Res. 2017, 61. [CrossRef] 
22. Su, M.; Dong, C.; Wan, J.; Zhou, M. Pharmacokinetics, tissue distribution and excretion study of trans-resveratrol-3-O-glucoside and its two metabolites in rats. Phytomedicine Int. J. Phytother. Phytopharm. 2019, 58, 152882. [CrossRef]

23. Boocock, D.J.; Patel, K.R.; Faust, G.E.S.; Normolle, D.P.; Marczylo, T.H.; Crowell, J.A.; Brenner, D.E.; Booth, T.D.; Gescher, A.; Steward, W.P. Quantitation of trans-resveratrol and detection of its metabolites in human plasma and urine by high performance liquid chromatography. J. Chromatogr. B Anal. Technol. Biomed. Life Sci. 2007, 848, 182-187. [CrossRef] [PubMed]

24. Walle, T. Bioavailability of resveratrol. Ann. N. Y. Acad. Sci. 2011, 1215, 9-15. [CrossRef]

25. Juan, M.E.; Maijó, M.; Planas, J.M. Quantification of trans-resveratrol and its metabolites in rat plasma and tissues by HPLC. J. Pharm. Biomed. Anal. 2010, 51, 391-398. [CrossRef] [PubMed]

26. Meng, X.; Maliakal, P.; Lu, H.; Lee, M.-J.; Yang, C.S. Urinary and plasma levels of resveratrol and quercetin in humans, mice, and rats after ingestion of pure compounds and grape juice. J. Agric. Food Chem. 2004, 52, 935-942. [CrossRef]

27. Aumont, V.; Krisa, S.; Battaglia, E.; Netter, P.; Richard, T.; Mérillon, J.M.; Magdalou, J.; Sabolovic, N. Regioselective and stereospecific glucuronidation of trans- and cis-resveratrol in human. Arch. Biochem. Biophys. 2001, 393, 281-289. [CrossRef]

28. Almeida, L.; Vaz-da-Silva, M.; Falcão, A.; Soares, E.; Costa, R.; Loureiro, A.I.; Fernandes-Lopes, C.; Rocha, J.-F.; Nunes, T.; Wright, L.; et al. Pharmacokinetic and safety profile of trans-resveratrol in a rising multiple-dose study in healthy volunteers. Mol. Nutr. Food Res. 2009, 53 (Suppl. S1), S7-S15. [CrossRef]

29. la Porte, C.; Voduc, N.; Zhang, G.; Seguin, I.; Tardiff, D.; Singhal, N.; Cameron, D.W. Steady-State pharmacokinetics and tolerability of trans-resveratrol $2000 \mathrm{mg}$ twice daily with food, quercetin and alcohol (ethanol) in healthy human subjects. Clin. Pharmacokinet. 2010, 49, 449-454. [CrossRef]

30. Boocock, D.J.; Faust, G.E.S.; Patel, K.R.; Schinas, A.M.; Brown, V.A.; Ducharme, M.P.; Booth, T.D.; Crowell, J.A.; Perloff, M.; Gescher, A.J.; et al. Phase I dose escalation pharmacokinetic study in healthy volunteers of resveratrol, a potential cancer chemopreventive agent. Cancer Epidemiol. Biomark. Prev. 2007, 16, 1246-1252. [CrossRef]

31. Wenzel, E.; Soldo, T.; Erbersdobler, H.; Somoza, V. Bioactivity and metabolism of trans-resveratrol orally administered to Wistar rats. Mol. Nutr. Food Res. 2005, 49, 482-494. [CrossRef]

32. Kapetanovic, I.M.; Muzzio, M.; Huang, Z.; Thompson, T.N.; McCormick, D.L. Pharmacokinetics, oral bioavailability, and metabolic profile of resveratrol and its dimethylether analog, pterostilbene, in rats. Cancer Chemother. Pharmacol. 2011, 68, 593-601. [CrossRef]

33. Marier, J.-F.; Vachon, P.; Gritsas, A.; Zhang, J.; Moreau, J.-P.; Ducharme, M.P. Metabolism and disposition of resveratrol in rats: Extent of absorption, glucuronidation, and enterohepatic recirculation evidenced by a linked-rat model. J. Pharmacol. Exp. Ther. 2002, 302,369-373. [CrossRef]

34. Chen, W.; Yeo, S.C.M.; Elhennawy, M.G.A.A.; Xiang, X.; Lin, H.-S. Determination of naturally occurring resveratrol analog trans-4, $4^{\prime}$-dihydroxystilbene in rat plasma by liquid chromatography-tandem mass spectrometry: Application to a pharmacokinetic study. Anal. Bioanal. Chem. 2015, 407, 5793-5801. [CrossRef]

35. Jannin, B.; Menzel, M.; Berlot, J.-P.; Delmas, D.; Lançon, A.; Latruffe, N. Transport of resveratrol, a cancer chemopreventive agent, to cellular targets: Plasmatic protein binding and cell uptake. Biochem. Pharmacol. 2004, 68, 1113-1118. [CrossRef]

36. Nair, M.S. Spectroscopic study on the interaction of resveratrol and pterostilbene with human serum albumin. J. Photochem. Photobiol. B 2015, 149, 58-67. [CrossRef]

37. N' soukpoe-Kossi, C.N.; St-Louis, C.; Beauregard, M.; Subirade, M.; Carpentier, R.; Hotchandani, S.; Tajmir-Riahi, H.A. Resveratrol binding to human serum albumin. J. Biomol. Struct. Dyn. 2006, 24, 277-283. [CrossRef]

38. Bode, L.M.; Bunzel, D.; Huch, M.; Cho, G.-S.; Ruhland, D.; Bunzel, M.; Bub, A.; Franz, C.M.A.P.; Kulling, S.E. In vivo and in vitro metabolism of trans-resveratrol by human gut microbiota. Am. J. Clin. Nutr. 2013, 97, 295-309. [CrossRef]

39. Azorín-Ortuño, M.; Yáñez-Gascón, M.J.; Vallejo, F.; Pallarés, F.J.; Larrosa, M.; Lucas, R.; Morales, J.C.; Tomás-Barberán, F.A.; García-Conesa, M.T.; Espín, J.C. Metabolites and tissue distribution of resveratrol in the pig. Mol. Nutr. Food Res. 2011, 55, 1154-1168. [CrossRef]

40. Wang, D.; Hang, T.; Wu, C.; Liu, W. Identification of the major metabolites of resveratrol in rat urine by HPLC-MS/MS. J. Chromatogr. B Anal. Technol. Biomed. Life Sci. 2005, 829, 97-106. [CrossRef] 
41. Basholli-Salihu, M.; Schuster, R.; Mulla, D.; Praznik, W.; Viernstein, H.; Mueller, M. Bioconversion of piceid to resveratrol by selected probiotic cell extracts. Bioprocess Biosyst. Eng. 2016, 39, 1879-1885. [CrossRef]

42. Qiu, Z.; Yu, J.; Dai, Y.; Yang, Y.; Lu, X.; Xu, J.; Qin, Z.; Huang, F.; Li, N. A simple LC-MS/MS method facilitated by salting-out assisted liquid-liquid extraction to simultaneously determine trans-resveratrol and its glucuronide and sulfate conjugates in rat plasma and its application to pharmacokinetic assay. Biomed. Chromatogr. BMC 2017, 31, e4001. [CrossRef]

43. Cottart, C.-H.; Nivet-Antoine, V.; Laguillier-Morizot, C.; Beaudeux, J.-L. Resveratrol bioavailability and toxicity in humans. Mol. Nutr. Food Res. 2010, 54, 7-16. [CrossRef]

44. Frankel, E.N.; Waterhouse, A.L.; Kinsella, J.E. Inhibition of human LDL oxidation by resveratrol. Lancet Lond. Engl. 1993, 341, 1103-1104. [CrossRef]

45. Miyagi, Y.; Miwa, K.; Inoue, H. Inhibition of human low-density lipoprotein oxidation by flavonoids in red wine and grape juice. Am. J. Cardiol. 1997, 80, 1627-1631. [CrossRef]

46. Belguendouz, L.; Frémont, L.; Gozzelino, M.T. Interaction of transresveratrol with plasma lipoproteins. Biochem. Pharmacol. 1998, 55, 811-816. [CrossRef]

47. Asadi, S.; Rahimi, Z.; Saidijam, M.; Shabab, N.; Goodarzi, M.T. Effects of Resveratrol on FOXO1 and FOXO3a Genes Expression in Adipose Tissue, Serum Insulin, Insulin Resistance and Serum SOD Activity in Type 2 Diabetic Rats. Int. J. Mol. Cell. Med. 2018, 7, 176-184.

48. St John, S.E.; Jensen, K.C.; Kang, S.; Chen, Y.; Calamini, B.; Mesecar, A.D.; Lipton, M.A. Design, synthesis, biological and structural evaluation of functionalized resveratrol analogues as inhibitors of quinone reductase 2. Bioorg. Med. Chem. 2013, 21, 6022-6037. [CrossRef]

49. Belguendouz, L.; Fremont, L.; Linard, A. Resveratrol inhibits metal ion-dependent and independent peroxidation of porcine low-density lipoproteins. Biochem. Pharmacol. 1997, 53, 1347-1355. [CrossRef]

50. Low, I.C.C.; Chen, Z.X.; Pervaiz, S. Bcl-2 modulates resveratrol-induced ROS production by regulating mitochondrial respiration in tumor cells. Antioxid. Redox Signal. 2010, 13, 807-819. [CrossRef]

51. Jung, K.-H.; Lee, J.H.; Thien Quach, C.H.; Paik, J.-Y.; Oh, H.; Park, J.W.; Lee, E.J.; Moon, S.-H.; Lee, K.-H. Resveratrol suppresses cancer cell glucose uptake by targeting reactive oxygen species-mediated hypoxia-inducible factor- $1 \alpha$ activation. J. Nucl. Med. 2013, 54, 2161-2167. [CrossRef]

52. Cao, L.; Chen, X.; Xiao, X.; Ma, Q.; Li, W. Resveratrol inhibits hyperglycemia-driven ROS-induced invasion and migration of pancreatic cancer cells via suppression of the ERK and p38 MAPK signaling pathways. Int. J. Oncol. 2016, 49, 735-743. [CrossRef]

53. Kong, Q.; Ren, X.; Hu, R.; Yin, X.; Jiang, G.; Pan, Y. Isolation and purification of two antioxidant isomers of resveratrol dimer from the wine grape by counter-current chromatography. J. Sep. Sci. 2016, 39, 2374-2379. [CrossRef]

54. Li, W.; Cao, L.; Chen, X.; Lei, J.; Ma, Q. Resveratrol inhibits hypoxia-driven ROS-induced invasive and migratory ability of pancreatic cancer cells via suppression of the Hedgehog signaling pathway. Oncol. Rep. 2016, 35, 1718-1726. [CrossRef]

55. Yar, A.S.; Menevse, S.; Alp, E.; Helvacioglu, F.; Take, G. The effects of resveratrol on cyclooxygenase-1 and cyclooxygenase-2 mRNA and protein levels in diabetic rat kidneys. Mol. Biol. Rep. 2010, 37, 2323-2331. [CrossRef]

56. Kutil, Z.; Temml, V.; Maghradze, D.; Pribylova, M.; Dvorakova, M.; Schuster, D.; Vanek, T.; Landa, P. Impact of wines and wine constituents on cyclooxygenase-1, cyclooxygenase-2, and 5-lipoxygenase catalytic activity. Mediat. Inflamm. 2014, 2014, 178931. [CrossRef]

57. Shen, M.Y.; Hsiao, G.; Liu, C.L.; Fong, T.H.; Lin, K.H.; Chou, D.S.; Sheu, J.R. Inhibitory mechanisms of resveratrol in platelet activation: Pivotal roles of p38 MAPK and NO/cyclic GMP. Br. J. Haematol. 2007, 139, 475-485. [CrossRef]

58. Jang, M.; Cai, L.; Udeani, G.O.; Slowing, K.V.; Thomas, C.F.; Beecher, C.W.; Fong, H.H.; Farnsworth, N.R.; Kinghorn, A.D.; Mehta, R.G.; et al. Cancer chemopreventive activity of resveratrol, a natural product derived from grapes. Science 1997, 275, 218-220. [CrossRef]

59. Kimura, Y.; Okuda, H.; Arichi, S. Effects of stilbenes on arachidonate metabolism in leukocytes. Biochim. Biophys. Acta 1985, 834, 275-278.

60. Yang, J.; Wang, N.; Li, J.; Zhang, J.; Feng, P. Effects of resveratrol on NO secretion stimulated by insulin and its dependence on SIRT1 in high glucose cultured endothelial cells. Endocrine 2010, 37, 365-372. [CrossRef] 
61. Huang, J.-P.; Hsu, S.-C.; Li, D.-E.; Chen, K.-H.; Kuo, C.-Y.; Hung, L.-M. Resveratrol Mitigates High-Fat Diet-Induced Vascular Dysfunction by Activating the Akt/eNOS/NO and Sirt1/ER Pathway. J. Cardiovasc. Pharmacol. 2018, 72, 231-241. [CrossRef]

62. Wiciński, M.; Malinowski, B.; Węclewicz, M.M.; Grześk, E.; Grześk, G. Resveratrol Increases Serum BDNF Concentrations and Reduces Vascular Smooth Muscle Cells Contractility via a NOS-3-Independent Mechanism. BioMed. Res. Int. 2017, 2017, 9202954. [CrossRef]

63. Maugeri, A.; Barchitta, M.; Mazzone, M.G.; Giuliano, F.; Basile, G.; Agodi, A. Resveratrol Modulates SIRT1 and DNMT Functions and Restores LINE-1 Methylation Levels in ARPE-19 Cells under Oxidative Stress and Inflammation. Int. J. Mol. Sci. 2018, 19, 2118. [CrossRef]

64. Della-Morte, D.; Dave, K.R.; DeFazio, R.A.; Bao, Y.C.; Raval, A.P.; Perez-Pinzon, M.A. Resveratrol pretreatment protects rat brain from cerebral ischemic damage via a sirtuin 1-uncoupling protein 2 pathway. Neuroscience 2009, 159, 993-1002. [CrossRef] [PubMed]

65. Tomé-Carneiro, J.; Gonzálvez, M.; Larrosa, M.; Yáñez-Gascón, M.J.; García-Almagro, F.J.; Ruiz-Ros, J.A.; Tomás-Barberán, F.A.; García-Conesa, M.T.; Espín, J.C. Grape resveratrol increases serum adiponectin and downregulates inflammatory genes in peripheral blood mononuclear cells: A triple-blind, placebo-controlled, one-year clinical trial in patients with stable coronary artery disease. Cardiovasc. Drugs Ther. 2013, 27, 37-48. [CrossRef]

66. Rivera, L.; Morón, R.; Zarzuelo, A.; Galisteo, M. Long-term resveratrol administration reduces metabolic disturbances and lowers blood pressure in obese Zucker rats. Biochem. Pharmacol. 2009, 77, 1053-1063. [CrossRef]

67. Beaudoin, M.-S.; Snook, L.A.; Arkell, A.M.; Simpson, J.A.; Holloway, G.P.; Wright, D.C. Resveratrol supplementation improves white adipose tissue function in a depot-specific manner in Zucker diabetic fatty rats. Am. J. Physiol. Regul. Integr. Comp. Physiol. 2013, 305, R542-R551. [CrossRef]

68. Bhatt, J.K.; Thomas, S.; Nanjan, M.J. Resveratrol supplementation improves glycemic control in type 2 diabetes mellitus. Nutr. Res. 2012, 32, 537-541. [CrossRef]

69. Brasnyó, P.; Molnár, G.A.; Mohás, M.; Markó, L.; Laczy, B.; Cseh, J.; Mikolás, E.; Szijártó, I.A.; Mérei, A.; Halmai, R.; et al. Resveratrol improves insulin sensitivity, reduces oxidative stress and activates the Akt pathway in type 2 diabetic patients. Br. J. Nutr. 2011, 106, 383-389. [CrossRef]

70. Thirunavukkarasu, M.; Penumathsa, S.V.; Koneru, S.; Juhasz, B.; Zhan, L.; Otani, H.; Bagchi, D.; Das, D.K.; Maulik, N. Resveratrol alleviates cardiac dysfunction in streptozotocin-induced diabetes: Role of nitric oxide, thioredoxin, and heme oxygenase. Free Radic. Biol. Med. 2007, 43, 720-729. [CrossRef]

71. Manna, S.K.; Mukhopadhyay, A.; Aggarwal, B.B. Resveratrol suppresses TNF-induced activation of nuclear transcription factors NF-kappa B, activator protein-1, and apoptosis: Potential role of reactive oxygen intermediates and lipid peroxidation. J. Immunol. Baltim. 2000, 164, 6509-6519. [CrossRef]

72. Estrov, Z.; Shishodia, S.; Faderl, S.; Harris, D.; Van, Q.; Kantarjian, H.M.; Talpaz, M.; Aggarwal, B.B. Resveratrol blocks interleukin-1beta-induced activation of the nuclear transcription factor NF-kappaB, inhibits proliferation, causes S-phase arrest, and induces apoptosis of acute myeloid leukemia cells. Blood 2003, 102, 987-995. [CrossRef]

73. Kanemaki, T.; Kitade, H.; Kaibori, M.; Sakitani, K.; Hiramatsu, Y.; Kamiyama, Y.; Ito, S.; Okumura, T. Interleukin 1 beta and interleukin 6, but not tumor necrosis factor alpha, inhibit insulin-stimulated glycogen synthesis in rat hepatocytes. Hepatol. Baltim. 1998, 27, 1296-1303. [CrossRef]

74. Haslbeck, K.-M.; Schleicher, E.; Bierhaus, A.; Nawroth, P.; Haslbeck, M.; Neundörfer, B.; Heuss, D. The AGE/RAGE/NF-(kappa)B pathway may contribute to the pathogenesis of polyneuropathy in impaired glucose tolerance (IGT). Exp. Clin. Endocrinol. Diabetes 2005, 113, 288-291. [CrossRef]

75. Li, W.; Ma, J.; Ma, Q.; Li, B.; Han, L.; Liu, J.; Xu, Q.; Duan, W.; Yu, S.; Wang, F.; et al. Resveratrol inhibits the epithelial-mesenchymal transition of pancreatic cancer cells via suppression of the PI-3K/Akt/NF-kB pathway. Curr. Med. Chem. 2013, 20, 4185-4194. [CrossRef]

76. Jiang, Z.; Chen, X.; Chen, K.; Sun, L.; Gao, L.; Zhou, C.; Lei, M.; Duan, W.; Wang, Z.; Ma, Q.; et al. YAP Inhibition by Resveratrol via Activation of AMPK Enhances the Sensitivity of Pancreatic Cancer Cells to Gemcitabine. Nutrients 2016, 8, 546. [CrossRef]

77. Olive, K.P.; Jacobetz, M.A.; Davidson, C.J.; Gopinathan, A.; McIntyre, D.; Honess, D.; Madhu, B.; Goldgraben, M.A.; Caldwell, M.E.; Allard, D.; et al. Inhibition of Hedgehog signaling enhances delivery of chemotherapy in a mouse model of pancreatic cancer. Science 2009, 324, 1457-1461. [CrossRef] 
78. Huang, H.; Lin, H.; Zhang, X.; Li, J. Resveratrol reverses temozolomide resistance by downregulation of MGMT in T98G glioblastoma cells by the NF-kB-dependent pathway. Oncol. Rep. 2012, 27, 2050-2056.

79. Kala, R.; Shah, H.N.; Martin, S.L.; Tollefsbol, T.O. Epigenetic-based combinatorial resveratrol and pterostilbene alters DNA damage response by affecting SIRT1 and DNMT enzyme expression, including SIRT1-dependent $\gamma$-H2AX and telomerase regulation in triple-negative breast cancer. BMC Cancer 2015, 15, 672. [CrossRef]

80. Xu, J.; Liu, D.; Niu, H.; Zhu, G.; Xu, Y.; Ye, D.; Li, J.; Zhang, Q. Resveratrol reverses Doxorubicin resistance by inhibiting epithelial-mesenchymal transition (EMT) through modulating PTEN/Akt signaling pathway in gastric cancer. J. Exp. Clin. Cancer Res. 2017, 36, 19. [CrossRef]

81. Giménez-Bastida, J.A.; Ávila-Gálvez, M.Á.; Espín, J.C.; González-Sarrías, A. Conjugated Physiological Resveratrol Metabolites Induce Senescence in Breast Cancer Cells: Role of p53/p21 and p16/Rb Pathways, and ABC Transporters. Mol. Nutr. Food Res. 2019, 63, e1900629. [CrossRef]

82. Chatterjee, B.; Ghosh, K.; Kanade, S.R. Resveratrol modulates epigenetic regulators of promoter histone methylation and acetylation that restores BRCA1, p53, p21CIP1 in human breast cancer cell lines. BioFactors Oxf. Engl. 2019, 45, 818-829. [CrossRef]

83. Singh, S.K.; Banerjee, S.; Acosta, E.P.; Lillard, J.W.; Singh, R. Resveratrol induces cell cycle arrest and apoptosis with docetaxel in prostate cancer cells via a p53/p21WAF1/CIP1 and p27KIP1 pathway. Oncotarget 2017, 8, 17216-17228. [CrossRef]

84. Mo, W.; Xu, X.; Xu, L.; Wang, F.; Ke, A.; Wang, X.; Guo, C. Resveratrol inhibits proliferation and induces apoptosis through the hedgehog signaling pathway in pancreatic cancer cell. Pancreatology 2011, 11, 601-609. [CrossRef]

85. Cilibrasi, C.; Riva, G.; Romano, G.; Cadamuro, M.; Bazzoni, R.; Butta, V.; Paoletta, L.; Dalprà, L.; Strazzabosco, M.; Lavitrano, M.; et al. Resveratrol Impairs Glioma Stem Cells Proliferation and Motility by Modulating the Wnt Signaling Pathway. PLoS ONE 2017, 12, e0169854. [CrossRef]

86. Kim, C.-W.; Hwang, K.-A.; Choi, K.-C. Anti-metastatic potential of resveratrol and its metabolites by the inhibition of epithelial-mesenchymal transition, migration, and invasion of malignant cancer cells. Phytomed. Int. J. Phytother. Phytopharm. 2016, 23, 1787-1796. [CrossRef]

87. Garvin, S.; Ollinger, K.; Dabrosin, C. Resveratrol induces apoptosis and inhibits angiogenesis in human breast cancer xenografts in vivo. Cancer Lett. 2006, 231, 113-122. [CrossRef]

88. Bishayee, A.; Waghray, A.; Barnes, K.F.; Mbimba, T.; Bhatia, D.; Chatterjee, M.; Darvesh, A.S. Suppression of the inflammatory cascade is implicated in resveratrol chemoprevention of experimental hepatocarcinogenesis. Pharm. Res. 2010, 27, 1080-1091. [CrossRef]

89. Salehi, B.; Mishra, A.P.; Nigam, M.; Sener, B.; Kilic, M.; Sharifi-Rad, M.; Fokou, P.V.T.; Martins, N.; Sharifi-Rad, J. Resveratrol: A Double-Edged Sword in Health Benefits. Biomedicines 2018, 6, 91. [CrossRef]

90. Berretta, M.; Della Pepa, C.; Tralongo, P.; Fulvi, A.; Martellotta, F.; Lleshi, A.; Nasti, G.; Fisichella, R.; Romano, C.; De Divitiis, C.; et al. Use of Complementary and Alternative Medicine (CAM) in cancer patients: An Italian multicenter survey. Oncotarget 2017, 8, 24401-24414. [CrossRef]

91. Xu, G.; Zhao, X.; Fu, J.; Wang, X. Resveratrol increase myocardial Nrf2 expression in type 2 diabetic rats and alleviate myocardial ischemia/reperfusion injury (MIRI). Ann. Palliat. Med. 2019, 8, 565-575. [CrossRef]

92. Yoshida, Y.; Shioi, T.; Izumi, T. Resveratrol ameliorates experimental autoimmune myocarditis. Circ. J. Off. J. Jpn. Circ. Soc. 2007, 71, 397-404. [CrossRef]

93. Guan, P.; Sun, Z.-M.; Wang, N.; Zhou, J.; Luo, L.-F.; Zhao, Y.-S.; Ji, E.-S. Resveratrol prevents chronic intermittent hypoxia-induced cardiac hypertrophy by targeting the PI3K/AKT/mTOR pathway. Life Sci. 2019, 233, 116748. [CrossRef]

94. Riba, A.; Deres, L.; Sumegi, B.; Toth, K.; Szabados, E.; Halmosi, R. Cardioprotective Effect of Resveratrol in a Postinfarction Heart Failure Model. Oxid. Med. Cell. Longev. 2017, 2017, 6819281. [CrossRef]

95. Chen, C.; Zou, L.-X.; Lin, Q.-Y.; Yan, X.; Bi, H.-L.; Xie, X.; Wang, S.; Wang, Q.-S.; Zhang, Y.-L.; Li, H.-H. Resveratrol as a new inhibitor of immunoproteasome prevents PTEN degradation and attenuates cardiac hypertrophy after pressure overload. Redox Biol. 2019, 20, 390-401. [CrossRef]

96. Sun, J.; Zhang, M.; Chen, K.; Chen, B.; Zhao, Y.; Gong, H.; Zhao, X.; Qi, R. Suppression of TLR4 activation by resveratrol is associated with STAT3 and Akt inhibition in oxidized low-density lipoprotein-activated platelets. Eur. J. Pharmacol. 2018, 836, 1-10. [CrossRef]

97. Cinoku, I.I.; Mavragani, C.P.; Moutsopoulos, H.M. Atherosclerosis: Beyond the lipid storage hypothesis. The role of autoimmunity. Eur. J. Clin. Investig. 2020, 50, e13195. [CrossRef] 
98. Bitorina, A.V.; Oligschlaeger, Y.; Shiri-Sverdlov, R.; Theys, J. Low profile high value target: The role of OxLDL in cancer. Biochim. Biophys. Acta Mol. Cell Biol. Lipids 2019, 1864, 158518. [CrossRef]

99. Lu, Z.; Wang, S.; Zhu, X.; Yuan, X.; Zhan, Y.; Li, Y.; Wang, W. Resveratrol Induces Endothelial Progenitor Cells Angiogenesis via MiR-542-3p by Targeting Angiopoietin-2 and Involves in Recanalization of Venous Thrombosis. Med. Sci. Monit. Int. Med. J. Exp. Clin. Res. 2019, 25, 7675-7683. [CrossRef]

100. Maurea, N.; Riva, L. Venous thromboembolism and atrial fibrillation in patients with cancer. G. Ital. Cardiol. 2006 2018, 19, 3S-6S.

101. Li, H.; Xia, N.; Hasselwander, S.; Daiber, A. Resveratrol and Vascular Function. Int. J. Mol. Sci. 2019, $20,2155$. [CrossRef]

102. Tolva, V.; Mazzola, S.; Zerbi, P.; Casana, R.; Albertini, M.; Calvillo, L.; Selmin, F.; Cilurzo, F. A successful experimental model for intimal hyperplasia prevention using a resveratrol-delivering balloon. J. Vasc. Surg. 2016, 63, 788-794. [CrossRef] [PubMed]

103. Kao, H.-H.; Kao, L.-T.; Li, I.-H.; Pan, K.-T.; Shih, J.-H.; Chou, Y.-C.; Wu, S.-T. Androgen Deprivation Therapy Use Increases the Risk of Heart Failure in Patients with Prostate Cancer: A Population-Based Cohort Study. J. Clin. Pharmacol. 2019, 59, 335-343. [CrossRef] [PubMed]

104. Quagliariello, V.; Rossetti, S.; Cavaliere, C.; Di Palo, R.; Lamantia, E.; Castaldo, L.; Nocerino, F.; Ametrano, G.; Cappuccio, F.; Malzone, G.; et al. Correction: Metabolic syndrome, endocrine disruptors and prostate cancer associations: Biochemical and pathophysiological evidences. Oncotarget 2017, 8, 62816. [CrossRef]

105. Mele, D.; Tocchetti, C.G.; Pagliaro, P.; Madonna, R.; Novo, G.; Pepe, A.; Zito, C.; Maurea, N.; Spallarossa, P. Pathophysiology of anthracycline cardiotoxicity. J. Cardiovasc. Med. Hagerstown Md 2016, 17 (Suppl. S1), S3-S11. [CrossRef]

106. Spallarossa, P.; Maurea, N.; Cadeddu, C.; Madonna, R.; Mele, D.; Monte, I.; Novo, G.; Pagliaro, P.; Pepe, A.; Tocchetti, C.G.; et al. A recommended practical approach to the management of anthracycline-based chemotherapy cardiotoxicity: An opinion paper of the working group on drug cardiotoxicity and cardioprotection, Italian Society of Cardiology. J. Cardiovasc. Med. Hagerstown 2016, 17 (Suppl. S1), S84-S92. [CrossRef]

107. McGowan, J.V.; Chung, R.; Maulik, A.; Piotrowska, I.; Walker, J.M.; Yellon, D.M. Anthracycline Chemotherapy and Cardiotoxicity. Cardiovasc. Drugs Ther. 2017, 31, 63-75. [CrossRef]

108. Quagliariello, V.; Vecchione, R.; Coppola, C.; Di Cicco, C.; De Capua, A.; Piscopo, G.; Paciello, R.; Narciso, V.; Formisano, C.; Taglialatela-Scafati, O.; et al. Cardioprotective Effects of Nanoemulsions Loaded with Anti-Inflammatory Nutraceuticals against Doxorubicin-Induced Cardiotoxicity. Nutrients 2018, 10, 1304. [CrossRef]

109. Quagliariello, V.; Coppola, C.; Mita, D.G.; Piscopo, G.; Iaffaioli, R.V.; Botti, G.; Maurea, N. Low doses of Bisphenol A have pro-inflammatory and pro-oxidant effects, stimulate lipid peroxidation and increase the cardiotoxicity of Doxorubicin in cardiomyoblasts. Environ. Toxicol. Pharmacol. 2019, 69, 1-8. [CrossRef]

110. Gu, J.; Fan, Y.-Q.; Zhang, H.-L.; Pan, J.-A.; Yu, J.-Y.; Zhang, J.-F.; Wang, C.-Q. Resveratrol suppresses doxorubicin-induced cardiotoxicity by disrupting E2F1 mediated autophagy inhibition and apoptosis promotion. Biochem. Pharmacol. 2018, 150, 202-213. [CrossRef]

111. Arafa, M.H.; Mohammad, N.S.; Atteia, H.H.; Abd-Elaziz, H.R. Protective effect of resveratrol against doxorubicin-induced cardiac toxicity and fibrosis in male experimental rats. J. Physiol. Biochem. 2014, 70, 701-711. [CrossRef]

112. Gordish, K.L.; Beierwaltes, W.H. Chronic resveratrol reverses a mild angiotensin II-induced pressor effect in a rat model. Integr. Blood Press. Control 2016, 9, 23-31. [PubMed]

113. Wong, R.H.X.; Howe, P.R.C.; Buckley, J.D.; Coates, A.M.; Kunz, I.; Berry, N.M. Acute resveratrol supplementation improves flow-mediated dilatation in overweight/obese individuals with mildly elevated blood pressure. Nutr. Metab. Cardiovasc. Dis. NMCD 2011, 21, 851-856. [CrossRef] [PubMed]

114. Zamora-Ros, R.; Urpi-Sarda, M.; Lamuela-Raventós, R.M.; Martínez-González, M.Á.; Salas-Salvadó, J.; Arós, F.; Fitó, M.; Lapetra, J.; Estruch, R.; Andres-Lacueva, C.; et al. High urinary levels of resveratrol metabolites are associated with a reduction in the prevalence of cardiovascular risk factors in high-risk patients. Pharmacol. Res. 2012, 65, 615-620. [CrossRef]

115. Magyar, K.; Halmosi, R.; Palfi, A.; Feher, G.; Czopf, L.; Fulop, A.; Battyany, I.; Sumegi, B.; Toth, K.; Szabados, E. Cardioprotection by resveratrol: A human clinical trial in patients with stable coronary artery disease. Clin. Hemorheol. Microcirc. 2012, 50, 179-187. [CrossRef] 
116. Militaru, C.; Donoiu, I.; Craciun, A.; Scorei, I.D.; Bulearca, A.M.; Scorei, R.I. Oral resveratrol and calcium fructoborate supplementation in subjects with stable angina pectoris: Effects on lipid profiles, inflammation markers, and quality of life. Nutrition 2013, 29, 178-183. [CrossRef]

117. Guthrie, A.R.; Chow, H.-H.S.; Martinez, J.A. Effects of resveratrol on drug- and carcinogen-metabolizing enzymes, implications for cancer prevention. Pharmacol. Res. Perspect. 2017, 5, e00294. [CrossRef]

118. Kulkarni, S.S.; Cantó, C. The molecular targets of resveratrol. Biochim. Biophys. Acta 2015, 1852, 1114-1123. [CrossRef] [PubMed]

119. Bitterman, J.L.; Chung, J.H. Metabolic effects of resveratrol: Addressing the controversies. Cell. Mol. Life Sci. CMLS 2015, 72, 1473-1488. [CrossRef]

120. Detampel, P.; Beck, M.; Krähenbühl, S.; Huwyler, J. Drug interaction potential of resveratrol. Drug Metab. Rev. 2012, 44, 253-265. [CrossRef]

121. Orsini, F.; Verotta, L.; Klimo, K.; Gerhäuser, C. Synthesis of Resveratrol Derivatives and In Vitro Screening for Potential Cancer Chemopreventive Activities. Arch. Pharm. 2016, 349, 414-427. [CrossRef]

122. Chow, H.-H.S.; Garland, L.L.; Hsu, C.-H.; Vining, D.R.; Chew, W.M.; Miller, J.A.; Perloff, M.; Crowell, J.A.; Alberts, D.S. Resveratrol modulates drug- and carcinogen-metabolizing enzymes in a healthy volunteer study. Cancer Prev. Res. 2010, 3, 1168-1175. [CrossRef]

123. Chang, T.K.H.; Chen, J.; Yu, C.-T. In vitro inhibition of rat CYP1A1 and CYP1A2 by piceatannol, a hydroxylated metabolite of trans-resveratrol. Drug Metab. Lett. 2007, 1, 13-16. [CrossRef]

124. Chen, Z.-H.; Hurh, Y.-J.; Na, H.-K.; Kim, J.-H.; Chun, Y.-J.; Kim, D.-H.; Kang, K.-S.; Cho, M.-H.; Surh, Y.-J. Resveratrol inhibits TCDD-induced expression of CYP1A1 and CYP1B1 and catechol estrogen-mediated oxidative DNA damage in cultured human mammary epithelial cells. Carcinogenesis 2004, 25, 2005-2013. [CrossRef]

125. Chow, H.-H.S.; Garland, L.L.; Heckman-Stoddard, B.M.; Hsu, C.-H.; Butler, V.D.; Cordova, C.A.; Chew, W.M.; Cornelison, T.L. A pilot clinical study of resveratrol in postmenopausal women with high body mass index: Effects on systemic sex steroid hormones. J. Transl. Med. 2014, 12, 223. [CrossRef]

126. Chiba, T.; Kimura, Y.; Suzuki, S.; Tatefuji, T.; Umegaki, K. Trans-Resveratrol Enhances the Anticoagulant Activity of Warfarin in a Mouse Model. J. Atheroscler. Thromb. 2016, 23, 1099-1110. [CrossRef]

127. Zhan, Y.-Y.; Liang, B.-Q.; Li, X.-Y.; Gu, E.-M.; Dai, D.-P.; Cai, J.-P.; Hu, G.-X. The effect of resveratrol on pharmacokinetics of aripiprazole in vivo and in vitro. Xenobiotica Fate Foreign Compd. Biol. Syst. 2016, 46, 439-444. [CrossRef]

128. Bedada, S.K.; Nearati, P. Effect of resveratrol on the pharmacokinetics of carbamazepine in healthy human volunteers. Phytother. Res. PTR 2015, 29, 701-706. [CrossRef]

129. McIlwain, C.C.; Townsend, D.M.; Tew, K.D. Glutathione S-transferase polymorphisms: Cancer incidence and therapy. Oncogene 2006, 25, 1639-1648. [CrossRef]

130. Cavalieri, E.; Rogan, E. The molecular etiology and prevention of estrogen-initiated cancers: Ockham's Razor: Pluralitas non est ponenda sine necessitate. Plurality should not be posited without necessity. Mol. Aspects Med. 2014, 36, 1-55. [CrossRef]

131. Yager, J.D. Mechanisms of estrogen carcinogenesis: The role of E2/E1-quinone metabolites suggests new approaches to preventive intervention-A review. Steroids 2015, 99, 56-60. [CrossRef]

132. Yu, C.; Shin, Y.G.; Kosmeder, J.W.; Pezzuto, J.M.; van Breemen, R.B. Liquid chromatography/tandem mass spectrometric determination of inhibition of human cytochrome P450 isozymes by resveratrol and resveratrol-3-sulfate. Rapid Commun. Mass Spectrom. 2003, 17, 307-313. [CrossRef]

133. International Agency for Research on Cancer. Global Cancer Observatory. Available online: https://gco.iarc.fr/ (accessed on 2 March 2020).

134. Miller, K.D.; Nogueira, L.; Mariotto, A.B.; Rowland, J.H.; Yabroff, K.R.; Alfano, C.M.; Jemal, A.; Kramer, J.L.; Siegel, R.L. Cancer treatment and survivorship statistics, 2019. CA: Cancer J. Clin. 2019, 69, 363-385. [CrossRef]

135. Wang, X.; Zhang, H.; Chen, X. Drug resistance and combating drug resistance in cancer. Cancer Drug Resist. 2019, 2, 141-160. [CrossRef]

136. Lichota, A.; Gwozdzinski, K. Anticancer Activity of Natural Compounds from Plant and Marine Environment. Int. J. Mol. Sci. 2018, 19, 3533. [CrossRef]

137. Rayan, A.; Raiyn, J.; Falah, M. Nature is the best source of anticancer drugs: Indexing natural products for their anticancer bioactivity. PLoS ONE 2017, 12, e0187925. [CrossRef] 
138. Lin, J.-N.; Lin, V.C.-H.; Rau, K.-M.; Shieh, P.-C.; Kuo, D.-H.; Shieh, J.-C.; Chen, W.-J.; Tsai, S.-C.; Way, T.-D. Resveratrol modulates tumor cell proliferation and protein translation via SIRT1-dependent AMPK activation. J. Agric. Food Chem. 2010, 58, 1584-1592. [CrossRef]

139. Vervandier-Fasseur, D.; Latruffe, N. The Potential Use of Resveratrol for Cancer Prevention. Mol. Basel Switz. 2019, 24, 4506. [CrossRef]

140. Berman, A.Y.; Motechin, R.A.; Wiesenfeld, M.Y.; Holz, M.K. The therapeutic potential of resveratrol: A review of clinical trials. NPJ Precis. Oncol. 2017, 1, 35. [CrossRef]

141. Ko, J.-H.; Sethi, G.; Um, J.-Y.; Shanmugam, M.K.; Arfuso, F.; Kumar, A.P.; Bishayee, A.; Ahn, K.S. The Role of Resveratrol in Cancer Therapy. Int. J. Mol. Sci. 2017, 18, 2589. [CrossRef]

142. Honari, M.; Shafabakhsh, R.; Reiter, R.J.; Mirzaei, H.; Asemi, Z. Resveratrol is a promising agent for colorectal cancer prevention and treatment: Focus on molecular mechanisms. Cancer Cell Int. 2019, 19, 180. [CrossRef]

143. de la Lastra, C.A.; Villegas, I. Resveratrol as an antioxidant and pro-oxidant agent: Mechanisms and clinical implications. Biochem. Soc. Trans. 2007, 35, 1156-1160. [CrossRef]

144. Albuquerque, R.V.; Malcher, N.S.; Amado, L.L.; Coleman, M.D.; Dos Santos, D.C.; Borges, R.S.; Valente, S.A.S.; Valente, V.C.; Monteiro, M.C. In Vitro Protective Effect and Antioxidant Mechanism of Resveratrol Induced by Dapsone Hydroxylamine in Human Cells. PLoS ONE 2015, 10, e0134768. [CrossRef]

145. Zhang, Q.; Tang, X.; Lu, Q.Y.; Zhang, Z.F.; Brown, J.; Le, A.D. Resveratrol inhibits hypoxia-induced accumulation of hypoxia-inducible factor-1alpha and VEGF expression in human tongue squamous cell carcinoma and hepatoma cells. Mol. Cancer Ther. 2005, 4, 1465-1474. [CrossRef]

146. Hinshaw, D.C.; Shevde, L.A. The Tumor Microenvironment Innately Modulates Cancer Progression. Cancer Res. 2019, 79, 4557-4566. [CrossRef]

147. Wang, M.; Zhao, J.; Zhang, L.; Wei, F.; Lian, Y.; Wu, Y.; Gong, Z.; Zhang, S.; Zhou, J.; Cao, K.; et al. Role of tumor microenvironment in tumorigenesis. J. Cancer 2017, 8,761-773. [CrossRef]

148. Yuan, Y.; Jiang, Y.-C.; Sun, C.-K.; Chen, Q.-M. Role of the tumor microenvironment in tumor progression and the clinical applications (Review). Oncol. Rep. 2016, 35, 2499-2515. [CrossRef]

149. Han, Y.; Jo, H.; Cho, J.H.; Dhanasekaran, D.N.; Song, Y.S. Resveratrol as a Tumor-Suppressive Nutraceutical Modulating Tumor Microenvironment and Malignant Behaviors of Cancer. Int. J. Mol. Sci. 2019, $20,925$. [CrossRef]

150. Luo, J.-L.; Maeda, S.; Hsu, L.-C.; Yagita, H.; Karin, M. Inhibition of NF-kappaB in cancer cells converts inflammation- induced tumor growth mediated by TNFalpha to TRAIL-mediated tumor regression. Cancer Cell 2004, 6, 297-305. [CrossRef]

151. Sharma, S.; Chopra, K.; Kulkarni, S.K.; Agrewala, J.N. Resveratrol and curcumin suppress immune response through CD28/CTLA-4 and CD80 co-stimulatory pathway. Clin. Exp. Immunol. 2007, 147, 155-163. [CrossRef]

152. Baek, S.H.; Ko, J.-H.; Lee, H.; Jung, J.; Kong, M.; Lee, J.; Lee, J.; Chinnathambi, A.; Zayed, M.E.; Alharbi, S.A.; et al. Resveratrol inhibits STAT3 signaling pathway through the induction of SOCS-1: Role in apoptosis induction and radiosensitization in head and neck tumor cells. Phytomedicine Int. J. Phytother. Phytopharm. 2016, 23, 566-577. [CrossRef]

153. Di Francia, R.; Berretta, M.; Benincasa, G.; D'Avino, A.; Facchini, S.; Costagliola, D.; Rossi, P. Pharmacogenetic-Based Interactions between Nutraceuticals and Angiogenesis Inhibitors. Cells 2019, 8, 522. [CrossRef]

154. Majeed, I.; Rana, A.; Rafique, M.; Anwar, A.W.; Mahmood, F. Time delay barriers in diagnosis and treatment of cancer. WCRJ 2018, 5, e1118.

155. D'Andrea, F.; Ceccarelli, M.; Rullo, E.V.; Facciolà, A.; D'Aleo, F.; Cacopardo, B.; Iacobello, C.; Costa, A.; Altavilla, G.; Pellicanò, G.F.; et al. Cancer screening in HIV-infected patients: Early diagnosis in a high-risk population. WCRJ 2018, 5, e1130.

(C) 2020 by the authors. Licensee MDPI, Basel, Switzerland. This article is an open access article distributed under the terms and conditions of the Creative Commons Attribution (CC BY) license (http://creativecommons.org/licenses/by/4.0/). 